\title{
The history of the Botanic Garden of Brera during the Restoration of the Austrian Empire and the early years of the Kingdom of Italy
}

\author{
Enrico Banfi ${ }^{1}$, Agnese Visconti ${ }^{2 *}$
}

\begin{abstract}
Here, we reconstruct the history of the Botanic Garden of Brera of Milan from the Restoration of the Austrian Empire up to the early years of the Kingdom of Italy, when in 1863 the garden passed hands from the Liceo di Sant'Alessandro to the Istituto Tecnico Superiore of Milan. The reconstruction is based mostly on unpublished documentation preserved at the Archivio di Stato of Milan, the Biblioteca Braidense of Milan, the libraries of the Museo di Storia Naturale of Milan and the Archivio di Stato of Milan, the Archivio del Liceo Classico Statale Cesare Beccaria of Milan, the historical archives of the Politecnico of Milan, the Biblioteca di Biologia Vegetale, Dipartimento di Scienze della Vita e Biologia dei Sistemi, University of Turin, the Autografoteca Botanica of the Botanical Garden of the University of Modena, and the library of the Botanical Garden of the University of Padova.

Overall, the period was one of slow decline for the Botanic Garden of Brera, against which successive directors - namely, Antonio Bodei, Francesco Enrico Acerbi, Giuseppe Balsamo Crivelli, Vincenzo Masserotti and Giustino Arpesani - combatted in vain. In particular, Balsamo Crivelli fought with great passion for many years to keep the level of the Botanic Garden of Brera at a satisfactory level, but he did not achieve the desired aim. However, he complied a partial list of the garden's plants, of which an updated version is presented here.
\end{abstract}

Key-words: Botanic Garden of Brera, Milan, $19^{\text {th }}$ century, Liceo di Sant'Alessandro, Istituto Tecnico Superiore.

Riassunto - Le vicende dell'Orto botanico di Brera durante il periodo della Restaurazione austriaca e i primi anni del Regno d'Italia. Il saggio ricostruisce - sulla base di una documentazione perlopiù inedita conservata nella Biblioteca Braidense di Milano, nell'Archivio di Stato di Milano, nella Biblioteca dell'Archivio di Stato di Milano; nella Biblioteca del Museo di Storia Naturale di Milano, nell'Archivio del Liceo Classico Statale Cesare Beccaria, nell'Archivio Storico del Politecnico di Milano; nella Biblioteca di Biologia Vegetale, Dipartimento di Scienze della Vita e Biologia dei Sistemi dell'Università degli Studi di Torino; nell'Autografoteca botanica dell'Orto dell'Università di Modena; nella Biblioteca dell'Orto botanico dell'Università di Padova - le vicende dell'Orto botanico di Brera durante il periodo della Restaurazione austriaca

\footnotetext{
${ }^{1}$ Sezione di Botanica, Museo di Storia Naturale di Milano, Corso Venezia 55, 20121 Milano, Italia

E-mail: enrbanfi@yahoo.it

${ }^{2}$ Via Podgora 3, 20122 Milano, Italia

*Corresponding author: visconti.agnese@gmail.com

(C) 2014 Enrico Banfi, Agnese Visconti
}

Received: $4^{\text {th }}$ October 2014

Accepted for publication: $12^{\text {th }}$ November 2014 fino a toccare i primissimi anni del Regno d'Italia, quando esso fu ceduto dal Liceo di Sant'Alessandro all'Istituto Tecnico Superiore (1863).

In complesso si trattò per l'Orto di un periodo di lenta decadenza contro la quale tentarono vanamente di opporsi i direttori che si susseguirono: Antonio Bodei, Francesco Enrico Acerbi, Giuseppe Balsamo Crivelli, Vincenzo Masserotti e Giustino Arpesani. Tra essi, in particolare Balsamo Crivelli si impegnò per molti anni nel tentativo di mantenere il livello dell'Orto a un grado soddisfacente, ma non riuscì a raggiungere i risultati sperati. Egli stese un elenco rimasto incompleto delle piante dell'Orto di cui si presentano in questa sede gli aggiornamenti nomenclaturali.

Parole chiave: Orto botanico di Brera, Milano, Ottocento, Liceo di Sant'Alessandro, Istituto Tecnico Superiore.

\section{The introduction of Austrian policies on education in the Kingdom of Lombardy-Venetia}

When Lombardy's annexation to the Austrian Empire was officially proclaimed on June 12,1814, after the fall of Napoleon (Meriggi, 1987: 14), the circumstances of the Botanic Garden of Brera remained essentially unchanged. The Garden, founded in Milan in 1774 by the empress of Austria Maria Theresa nearby the Scuole Palatine, with the aim of teaching botany to the physicians and the apothecarists (Visconti, 2012), had been annexed in 1802 - after the conquest of Lombardy by the French army (1796) - to the Liceo dell'Olona (Banfi \& Visconti, 2013). On this one, which was officially renamed the Liceo di Sant'Alessandro because of the relocation to the buildings of the eponymous college (Conte, in press,) it continued to depend for the lessons of botany. The comunication of the decision of the Austrian public power was given on December 17 of that year by the temporary plenipotentiary, Field Marshal Heinrich de Bellegarde (Meriggi 1987: 11) who informed the Director of Public Education Giovanni Scopoli that the subjects taught in Lombardy and the teaching methods used up to then would not be changed ${ }^{1}$. However, shortly after the establishment of the Kingdom of Lombardy-Venetia with the Letter Patent of April 7, 18152, and following the gradual consolidation of its governmental bodies, Vienna took a firmer hold on issues related to education, and began reforming the licei in order to standardise them with those of Austria and reduce the weight given to scientific subjects (Giglio, 1978). As a first step, the Governor of Lombardy, Franz 
Saurau - appointed in Milan in May 1815 - sent a request to Scopoli for an assessment of the licei. The evaluation was delivered to the Governor on October 24, 1815, and indicated, among other things, the existence in almost all licei of botanic or agricultural gardens equipped with rooms for the shelter of exotic plants during the winter ${ }^{3}$. This was followed on October 15, 1816, by a circular from Scopoli to the provincial delegates, ordering the directors of the licei to compile an inventory of premises, furniture, scientific equipment, books and gardens of the institutions they headed ${ }^{4}$.

\section{The directorships of Antonio Bodei and Francesco Enrico Acerbi}

In 1816, Dr Antonio Bodei from Brescia (1777-1822) ${ }^{5}$ was appointed Provisional Professor of Natural History at the Liceo di Sant'Alessandro. He had graduated in medicine at Padua University, had practiced in Brescia, where he was the Chancellor of the Medical Delegation, and then had been appointed Professor of Physics, first at Belluno and then at Urbino (Schivardi, 1839). Upon the return in 1814 of Urbino under the Papal State, he had remained quiescent and, as such, was chosen by the Austrian Government as chair of natural history at the Liceo di Sant' Alessandro, and given also the management of the Garden ${ }^{6}$. Bodei took over from the chemist and apothecary Paolo Sangiorgio (1748-1816), who taught botany and not natural history, but was free to teach the later discipline under the Napoleonic Decree for Licei of November 5, 1811, which, despite having incorporated the chair of botany onto that of natural sciences, had granted some professors - among which was Sangiorgio - the possibility to continue teaching until "death, demission or cause otherwise" (Bollettino delle Leggi del Regno d'Italia, 1811). After the death of Sangiorgio, the chair of botany was not renewed by the Austrians, who reaffirmed its abolition with the Sovereign Resolution of November 9, 1816, stating that all licei should have a chair of general natural history, and that the chairs of chemistry, botany and agriculture be abolished ${ }^{7}$. Thus, Milan lost all teaching of botany, a subject that had been introduced in 1774 by the Vallombrosan abbot Fulgenzio Vitman (17281806) (Visconti, 2012).

The lessening of the subject's status was to continue even further, and along with it also that of natural history. In fact, the Plan for the Accomplishment of the Studies in the Royal Licei - issued on October 15, 1817, by a decree of Vienna's Aulic Commission for Organisation - set out that natural history would be taught seven hours per week in the third year and that it would be compulsory only for physicians; it was later extended also to engineers, architects and surveyors, as made clear in a letter dated October 9, 1818, sent by the Government to the jurist Gulio Padulli, who was acting director of the Liceo di Sant'Alessandro ${ }^{8}$. The number of hours were then reduced to five ${ }^{9}$ and, later, with the Plan for Philosophical Studies of October 30,1824, to four, with the recommendation that natural history should not be taught only in connection with the study of medicine, but should be extended also to other students so that they too could gain from it. Therefore, professors would have to teach natural history in general, keeping in mind its utility in social, agricultural and forestry spheres (Raccolta degli Atti di Governo, 1825). The result of these reductive decisions was the Sovereign Resolution of June 2, 1826, which was followed by the Aulic Decree of June 24 of the same year, which - notwithstanding the repeated outcries of the directors of the licei, the deputy director of the Faculty of Philosophy of the University of Pavia, Pietro Configliachi, and the Government itself - abolished the botanic gardens of all provinces, except those of Milan and Mantua ${ }^{10}$.

The Botanic Garden of Brera was undoubtedly saved also because of a passionate description of its role given by the new director of the Liceo di S. Alessandro, Angelo Maria Bignami, who was appointed Padulli's successor by the Aulic Chamber on July 19, $1819^{11}$ : in his long letter to the Government, dated September 12,1820 - which he had drafted before the abolition of the botanic gardens had been decreed - he had explained the dual function of the Garden of Brera, which on the one hand was used for educational purposes, and on the other was open to the public. In fact, the Garden was useful not only for the students of the two licei who "after their theoretical lectures, would go on to obtain confirmation of the doctrines of the vegetable kingdom through demonstrations" with the plants prepared by the head gardener, but also "to the many amateurs and, in particular, to the pharmacists and technicians of the Imperial Royal Forestry Authority". He then went on to point out its invaluable role in Milan as a model for the many private gardens that were appearing ever more numerous than in any other city of the Italian peninsula, and finally declared that devotees of botany would always turn to the Garden of Brera for education in the progresses being made in that science ${ }^{12}$.

The primary and most immediate purpose of Bignami's letter had been to prevent cutbacks in funding and personnel. In fact, the position of curator at the Garden had been vacant since the death of Filippo Armano (1762-1817), who for many years had worked with great zeal in transforming it into an institution suitable for growing not only medicinal herbs, but also exotic, rare and ornamental plants, giving rise to its dual teaching and public role mentioned above. Collaborating with the best and most-famous European horticulturists and amateurs of botany, he had devoted himself to the end in the acquisition of valuable plants, as illustrated in a note ${ }^{13}$ written shortly before his death to Archduke John Habsburg-Lorraine of Austria - who had a strong interest in the natural sciences (Österreichisches Biographisches Lexicon, 1961) - in which he requested a large number of rare and ornamental plants for the Garden of Brera.

Bignami had waited in vain for the Government's Department of Studies - which had taken over from the Directorate General of Public Education in April 12, 1817 (Raccolta degli Atti del Governo, 1817) - to spontaneously appoint a new curator. Hence the decision of the director of the Liceo di Sant'Alessandro to apply directly to the Department of Studies for the assignment of a curator who would be responsible for liaising with other botanic gardens for the exchange of plants; for 
overseeing the sowing, transplantation, grafting and attempts of naturalisation of the exotic plants by the head gardener; and, finally, for picking medicinal plants from the countryside ${ }^{14}$. The Government accepted Bignami's request and asked a curator for the Garden to the Aulic Chancellery of Vienna on January 25, 1822, suggesting the position be filled by Domenico Odescalchi ${ }^{15}$. But on June 21 of the following year, the Aulic Chancellery deliberated that since the botanic gardens of the licei were intended as a tool for the study of general natural history, it followed that the professor of the discipline could also manage them ${ }^{16}$.

After little less than a year, the new director of the Liceo di Sant'Alessandro, Cesare Frapolli17, picked up the issue again in a letter dated March 22, 1824, to the Government in which he not only reiterated the reasons set out by Bignami, but added that professors of general natural history were not obliged to have an in-depth knowledge of botany; that due to the absence of a curator, the Garden did not have a catalogue of the plants cultivated there; that there was no network of collaborating institutions; that it had no documentation on the practical observations and rules of cultivation, on the periods of flowering, on the accidental varieties that had arisen, or on the quality and uses of the most important plants cultivated there; and, finally, that it did not even have a subscription to a journal that would allow the professor to keep track of the progresses being made in botany ${ }^{18}$. The letter remained unanswered, and Frapolli found himself repeating the seriousness of the lack of a curator $^{19}$, but again to no avail. Instead, he received from Vienna the Sovereign Resolution of June 2, 1826, in which it was finally decreed that the administration of the Garden was up to the professor of natural history, who was to be considered also curator under the supervision of the liceo's director ${ }^{20}$.

Returning to Bodei - in an attempt to understand his contribution to the Botanic Garden of Brera - we find confirmation of what was written by Frapolli, namely that a professor of general natural history was not necessarily an expert in botany. Bodei - who, as pointed out above, was a physician that had taught physics before being appointed to Milan - does not seem to have harboured any special interest in botany. In fact, his publications dealt mostly with epidemic diseases, with the exception of his booklet Alcuni cenni sulle produzioni naturali di Metauro (Guerrini, Urbino, 1813) co-authored with Giovanni de Brignoli di Brunnhof, and there is no evidence, as far as we can ascertain, of documents relating to exchanges or acquisitions of plants and seeds. The only suggestion we have of him taking an interest in the Garden is his signalling to Frapolli ${ }^{21}$ - in his capacity as director, and as such a person in a position to correspond with the Government - of the need to act on the Garden's obsolete and dilapidated wooden structures and walls ${ }^{22}$. In his letter of March 3, 1822, Bodei did in fact notice the poor state of one of the Garden's two ponds, which required the construction of a new, stable and sturdy staircase because the steps were worn out and broken and, therefore, unfit to bear the pots that were placed upon it. A few months later, Bodei's request was approved by the President of the
Government, Giovanni Bazetta ${ }^{23}$. However, the Brescian physician's interest in the Garden was not destined to last long: in 1820, the Government Counsellor Febo d'Adda gave him the lengthy and difficult task of cataloguing the extensive natural history collection donated to the Liceo di Sant'Alessandro by the geologist and mineralogist Ermenegildo Pini in $1813^{24}$. This assignment was the first signal of the importance that Vienna was starting to attach to collections of natural history, considered more suitable tools for the teaching of general natural history than were botanic gardens. Indeed, this discipline required in the opinion of the Imperial Royal Aulic Commission for Studies of Vienna - "many demonstrations and illustrations, by means of individual specimens of the three kingdoms of nature, as well as a sufficient number of natural objects of all types, in order to demonstrate the characters of any order and some of the species of these orders", beginning with minerals, for which it needed a complete collection, similar to that donated by Pini. However, according to the Commission, it was sufficient that the plant and animal kingdoms be illustrated with only a few, native species, which a professor could easily procure $^{25}$. The importance attached to these collections grew as a result, so that on December 4,1824 , just as the abolition of the botanic gardens was being discussed, Vienna decided to allocate 200 lira for every liceo, with the exception of the Liceo di Sant'Alessandro, which was given 230 lira as ordinary funding for the formation and development of these educational tools ${ }^{26}$.

The task of cataloguing Pini's natural history collection proved challenging for Bodei, who probably ended up neglecting the Garden, entrusting its care to the gardener Giacomo Seveso and his assistant Mauro Volpi. Despite their extensive experience - the former had started work as a gardener in 1793 (Visconti, 2012) and the latter had been hired in 1803 (Banfi \& Visconti, 2013) - they were not capable of acting without the guidance of a supervisor ${ }^{27}$. In the end, the Brescian doctor did not succeed in completing the catalogue: he died in $1822^{28}$, leaving the work unfinished.

Dr Francesco Enrico Acerbi (1784 or 1785-1827) was subsequently called to provisionally cover the chair of natural history at the Liceo Sant'Alessandro and the management the Garden. He had graduated in medicine at Pavia in 1810, then became first a physician at the Ospedale Maggiore (Latronico, 1935: 17-18; Villa, 1956; Caracciolo, 1960) and then professor of natural history at the Liceo di Porta Nuova since 1817. He was a friend of the writer Alessandro Manzoni, who turned to him for the medical aspects for his historical novel The Betrothed (orig. Italian: I Promessi Sposi) (Latronico, 1935: 20; Le scuole dei Barnabiti, 1933: 112; Villa, 1956). Upon taking up his duties as professor at the Liceo di Sant'Alessandro' ${ }^{29}$, Acerbi resigned as chair of the Liceo di Porta Nuova, which was temporarily entrusted to the engineer Carlo Paganini $^{30}$. But shortly after, Acerbi was called by the Government to cover the chairs of both licei ${ }^{31}$. Adding to the burden of this task was the continuation of cataloguing Pini's natural history collection ${ }^{32}-$ which, as mentioned above, Bodei had not terminated - and, in compliance with an invitation made by the Government, also the 
drafting of a study guide for the course of general natural history to replace the outdated text of Johann Christian Polycarp Erxleben, Anfangsgründe der Naturgeschichte (Dietrich, Göttingen und Gotha, 1773) proposed by the Aulic Commission waiting for a more suitable manual ${ }^{33}$.

In the meanwhile, the Botanic Garden of Brera had degraded further, especially with regards to the emphatically so-called greenhouse where the exotic plants were wintered. This structure was in need of urgent repairs and was, in fact, awaiting to be rebuilt from scratch as a proper greenhouse according to a plan submitted to the Government on May 6, 1824, by the official architect, Pietro Gilardoni ${ }^{34}$. But the project, which entailed an outlay of 25,000 lira, never came to fruition because the sum was repeatedly excluded from the annual expenditure estimates of the Board of Public Education ${ }^{35}$. Thus, work was limited to the most urgent repairs as they arose ${ }^{36}$.

Once the survival of the Garden had been decreed, as we have seen, it became necessary to provide it with the means for its operation. To this end, Emperor Francis I's Resolution of June 24, $1826^{37}$, assigned it an annual fund of 350 florins - equivalent to 1,050 lira - for the cultivation of plants and for expenses regarding minor repairs and rebuilding. This amount was destined to remain unchanged throughout the period of Austrian rule. The resolution also decreed that the administration and custody of the Garden, the supervision of the gardener and his assistant, as well as the compilation of a catalogue of existing plants were entrusted to the professor of natural history, under the supervision of the director of the liceo. A regulation was finally issued, stating that:

"I. The Botanic Garden is destined above all to the teaching of botany in Milan's two licei and technical schools $^{38}$. Amateurs may procure their education therein, under the supervision of the gardeners, who must lend their time.

II. The gardener and assistant are under the immediate orders of the professor, must follow his orders, and are obliged to work at the Garden. The gardener shall not only order the necessary work, but lend a hand in it. The assistant shall be subject to the gardener's orders.

III. The working day begins at dawn and end at sunset. On public holidays, the gardeners shall be amenable for all essential work, including the heating of the greenhouse, which in winter shall be performed also at night.

IV. Because the gardener must serve especially for the educational purposes of the Garden, he shall see to it that there is order in the two quadrants that include the systems, and shall be amenable to any needs of education, including the students of the technical school.

$\mathrm{V}$. It is forbidden to sell plants, even ones duplicated, without the knowledge of the professor, who shall see that all revenue be recorded and the money held to increase the funds.

VI. It shall be forbidden to practise layering and offshooting or other means of propagation of any plant without permission from the professor.

VII. The gardener is obliged to keep an accurate register of duplicate plants in order to meet the requests of other botanic gardens and facilitate exchange and purchases as shall be deemed necessary by the professor.

VIII. The gardener is obliged to collect seeds, which shall be marked with their name and compiled in a catalogue in alphabetical order, for exchange with seeds from other botanic gardens in November of each year.

IX. The gardener shall also take delivery of potted plants, which shall be compiled in a catalogue in double copy by the professor. For bedded plants, the catalogue shall be compiled little by little in the spring.

$\mathrm{X}$. It is forbidden to use the wood purchased for the greenhouse, but the gardener and assistant shall be allowed to share the remains deriving from the pruning of plants, with the permission of the professor" 39 .

Acerbi, overloaded with commitments at the Ospedale Maggiore, lecturing at the two licei and the cataloguing of Pini's natural history collection, was unable to perform the duties set out in the regulation. As a result, the Garden remained not only without its catalogue, but in all likelihood also without exchanges with other botanic gardens and new acquisitions, as inferred from the total lack of documents to this regard, at least as we have been able to assess up to now. What is more, as for Bodei, Acerbi's main interest was medicine, the field in which he published many important and respected works. His directorship was short-lived: he died on December 5, $1827^{40}$, after falling ill. He had been replaced, on Frapolli's advice ${ }^{41}$, in December of the previous year by the Milanese naturalist Giuseppe Balsamo Crivelli (18001874).

\section{Giuseppe Balsamo Crivelli and his passionate battles for the improvement of the Garden}

Balsamo Crivelli officially obtained the position of chair of natural history at the two licei on December 22, $1827^{42}$. After having tried in vain in 1821 to be accepted as a student at the Academy of Schemnitz ${ }^{43}$, he had graduated in medicine at Pavia in 1824 (Gliozzi, 1963) and had begun, even before his appointment, to work fervently at the Garden, which we know at the time "[could] not be said to be filled with exotic plants". In fact, as we infer from Cesare Rovida (1829: 35), "including the species grown in pots, which [amounted] to one thousand, and the various selected indigenous plants, there [were] from 3,500 to 4,000 specimens at the most, a number not sufficient to constitute a rich botanic garden", but yet it "[was] adequate for the elementary education of the two licei, which [did not have] a specific chair of botany". Balsamo Crivelli immediately started a correspondence for the exchange of plants and seeds with the Milanese naturalist-nobleman Giuseppe De Cristoforis (1803$1837)^{44}$, whose rich collections were destined to constitute - together with those of Giorgio Jan (1791-1866), an Italian naturalist of Hungarian origin - the original core of the Museo Civico di Storia Naturale di Milano, founded on May 7, 1838 (Conci, 1967: 28; Visconti, 1988: 3-4). In that same period, Balsamo Crivelli accepted the invitation of Frapolli to "compile a suitable textbook of natural history, applicable to the fourth class of superior and normal schools," following the wishes of the Aulic Commission for Studies ${ }^{45}$. He probably began to lend a hand in the 
task, but he did not finish it on account of his excessive workload during the whole period of his directorship. With regard to the Garden more specifically, it first of all needed an updated catalogue, which, as mentioned above, Frapolli had complained the lack of. To begin to fill this gap, Balsamo Crivelli sent the liceo's director already on September 6, 1827, a list of flowering plants, stating that "although a number may have escaped me, I did try to observe them all, numbering more than one thousand five hundred, and I made dried specimens of them in their entirety. I have not determined many of the plants, which I had reserved to accomplish within this year, were it not some special circumstances and my not being able to consult what works would be necessary. The purpose of this prospectus is the facilitation of the compilation of a catalogue raisonné necessary in all botanic gardens so that disorder may be avoided. Besides this prospectus, I anticipate that I have already extended the catalogue to all bedded plants, many of which I may not determine exactly the species because not yet in bloom" ${ }^{\prime 46}$. The work continued, as evidenced by a list of more than 650 pot plants compiled in 1846, which we have published here because it represents the only document found that gives an at least partial representation of the range of plants in the Garden that year ${ }^{47}$.

But the Garden was burdened by other urgent problems, as explained in a letter sent by Balsamo Crivelli to Frapolli, dated January 16, 1828, so that he might report them to the Government: firstly, there were fundamental repairs needed to the plumbing and masonry, which could not be paid for with the ordinary yearly funds of 1,050 lira; second, there was a need "to build a tank for the greenhouse waters, since, having to conduct them from the outside, this [produced] a continuous cooling action"; third, it was asked that the director be housed at the Garden so that he might be better able to understand its daily requirements and especially the wood needed to heat the premises used for the winter storage of plants, which, it was feared, the gardener was stealing ${ }^{48}$. Shortly after, he called attention also to the need to repair stretches of the Garden's wall, in particular those that separated it from the adjacent Villa Trotti ${ }^{49}$. Of the Milanese naturalist's requests, the Government considered only the masonry work, stating that it had instructed the State Property Office to deal with it ${ }^{50}$.

To the issues set out by Balsamo Crivelli was then added the need to channel rainwater from the roof of Brera Building to prevent it gushing into the Garden. This repair work, initiated by the architect Pietro Gilardoni and later by the official engineer Carlo Caimi, was completed in August 1831, after years of delay ${ }^{51}$.

Meanwhile, Balsamo Crivelli asked again for accommodations at the Brera Building, referring to the decree of June 24, 1826, stating that "the Professor of Natural History [should] be considered the curator of the Garden, and thus should supervise its work and administration," and pointing out that all the curators of all the other institutions at Brera Building had spacious and comfortable apartments, "albeit the objects they [were] in charge of maintaining [demanded] less attention than plants" ${ }^{\prime 2}$. In the same year, in face of the indifference and narrow-mindedness of the Government, he assumed the defence of the gardener and assistant regarding the use of wood for activities not set out in article $\mathrm{X}$ of the regulations of 1826, with the following words: "The greenhouse takes just two hours to cool down in the winter and kill many plants. Consequently, the gardener must be continually vigilant, and it is right that he should have the means to defend against the cold. Thus, he should be able to use the wood limited to that use" ${ }^{3}$. But the Government responded to Frapolli with a dispatch on March 18, 1830, in which it was argued that the teaching of botany had no longer been practiced at the Garden for many years, since the lectures were being conducted at the two licei with the use of potted plants transported there for the demonstrations, and concluding that the students were sometimes sent to the Garden only in summer so that they might examine those plants the nature and magnitude of which impeded their transportation ${ }^{54}$ : these words made the Government's absolute indifference to the problems of the Garden clear and unequivocal.

However, the insistence of Balsamo Crivelli and his descriptions of the increasingly ruinous state of the greenhouse were $\operatorname{such}^{55}$ that the General Directorate of Public Constructions instructed Caimi to verify the need of repair work. Caimi acknowledged the dilapidated state of the greenhouse ${ }^{56}$, but he did not express the need for repair work or for a new construction ${ }^{57}$. In fact, nothing happened. And so, on April 15, 1831, the Milanese naturalist was forced to send Frapolli a new petition in which he complained about not having "permanent housing" despite being obliged by the decree of June 24, 1826, "to attend to all work and the proper functioning of the Garden, and to classify and determine the plants, and keep notes on them, and so to frequently remain for long periods in the Garden"; he also pointed out that many tasks had been nonetheless done, including the reordering of half of the Garden, which had been prepared according to the natural system of the Swiss botanist Augustin Pyramus de Candolle ${ }^{58}$; he concluded that the residence requested would serve to keep not only the books necessary for the determination of plants that were often brought there by amateurs, but also the microscope used to demonstrate plant anatomy to the students ${ }^{59}$. Archduke Ranieri Habsburg-Lorraine, Viceroy of Lombardy ${ }^{60}$, finally intervened to resolve the housing issue, giving Balsamo Crivelli permission to use the apartment of Antonio Maderna, the curator of the Academy of Fine Arts ${ }^{61}$. However, the seriousness of the Garden's condition continued to worsen, and subsidence of the greenhouse forced Balsamo Crivelli to write, on October 18, 1832, for the umpteenth time to Frapolli, warning him about the inability to guarantee the plants' conservation $^{62}$. The Directorate of Public Constructions then instructed a new inspection by Caimi, who proposed changes to Gilardoni's 1824 project for the complete overhaul of the greenhouse, but noted that the danger of a total collapse was not imminent and that they could "get by" for a few more years ${ }^{63}$.

However, the incessant anxiety for the Garden's difficulties did not prevent Balsamo Crivelli intensifying his botanical correspondence with De Cristoforis. In 
1831, he contacted Giorgio Jan - the Italian naturalist of Hungarian origin, professor of botany at the University of Parma, and great friend of De Cristoforis, to the point that they fused their scientific collections that same year (Conci, 1967: 13) - for a collection of seeds ${ }^{64}$, and thus began a correspondence that, as we shall see, was not only beneficial for the Garden, but also brought new perspectives to the scientific activity of Balsamo Crivelli.

However, before initiating his botanical relationship with Jan, the Milanese naturalist, driven by a desire to broaden his knowledge and open up to other fields of natural history, decided to take a field trip to the southern provinces of the Italian peninsula. He suggested to the director of the Liceo di Sant'Alessandro, Gabrio Casati - who temporarily had taken the place of the ill Frapolli - to hire Giuseppe De Notaris as a substitute during his absence and at his expense ${ }^{65}$. This young doctor had graduated in Pavia in 1830 and then had worked at the Ospedale Maggiore in Milan, beginning a collaboration with Balsamo Crivelli on mosses (Garbari, 1990). At first, Governor Franz Hartig denied permission, arguing that the journey "[did not result to be] absolutely necessary and a benefit for public education, and [could be] deferred until a major school holiday"66. But he was soon forced to change his decision by Archduke Ranieri, who personally supported Balsamo Crivelli's request ${ }^{67}$.

On his return from the trip, Balsamo Crivelli donated many specimens to the Liceo di Sant'Alessandro; he also gave the Garden many seeds from botanic gardens of Rome and Florence, and also a specimen of "a very rare living plant, the Italian stapelia (Stapelia europaea Guss.), not cultivated at the Garden, as seems from the Catalogus plantarum Horti Regii Botanici Braydensis ad Annum MDCCCXII, written by Armano (Banfi \& Visconti, 2013), also donating examples to the gardens of Pavia and Monza"68.

In the meantime, the conditions at the Garden continued to deteriorate to the point that in June 1833, Balsamo Crivelli, disappointed by the ineffectiveness of his repeated warnings and alerts, decided to participate in the call for a new chair of agriculture at the University of Pavia ${ }^{69}$. The chair had been covered until then by Giuseppe Moretti (1782-1853), whose appointment as professor of botany that year had made the post available. The Milanese naturalist did not win the call, and the chair of agriculture returned to Moretti, who held it as a substitute until 1835 (Memorie e documenti, 1878: 434). Hence, Balsamo Crivelli remained in Milan, and continued teaching at the two licei and looking after the Garden. He resumed his correspondence with Jan, asking him on March 3, 1833, for a collection of seeds and apologizing for not being able to send anything in exchange, because, in his absence, the gardener had collected "only a few seeds [...] of very little importance". The request - to which Jan did not respond - was repeated on April 9, 1834, accompanied by an appeal for suggestions on the classification of certain plants. Subsequently, on April 25, 1835, he offered Jan seeds and plants, including some collected in Sardinia by his pupil De Notaris ${ }^{70}$.
The collaboration with De Notaris started becoming increasingly close, so much so that the two naturalists co-published Prodromus bryologiae mediolanensis (Rusconi, Mediolani, 1834), soon followed by Pugillus muscorum Italiae (Regia Typographia, Taurini, [1836?]) - both of which constituted the continuation of works published by Balsamo Crivelli after returning from his trip to the southern part of the Italian peninsula -Synopsis muscorum (Rusconi, Mediolani,1833) and Enumerazione delle piante crittogame (I.R. Stamperia, Milan, 1833). However, the collaboration was not to continue for long because, as we shall see, the interests of Balsamo Crivelli turned to other fields of the natural sciences.

The problems of the Garden continued to loom ever more threateningly and worryingly, to the point that in 1834 the Milanese naturalist and Frapolli took the decision $^{71}$ to use the ordinary funds, intended, as we have seen, only for small repairs, to pay for the most pressing interventions on the so called greenhouse. Debts thus began to accumulate, continuing even in the years that followed. However, they were made without producing any real or lasting improvements to the Garden. In fact, the situation required decisive and comprehensive projects and financial commitment, rather than the policy of procrastination that the Government had continued to follow, excluding year after year from the annual expenditure estimates of the Board of Public Education the sums needed for the greenhouse's reconstruction ${ }^{72}$. Shortly after, Balsamo Crivelli informed the Directorate of Public Constructions - which in turn wrote to the Government on July 20, 1835 - of the need to build a porch to shelter pots and tools, but the Government once again postponed all expenses, as can be gleaned from the minutes of the Board of Public Education meeting of September 14, 1835. However, the Directorate of Public Constructions approved repairs to the roof, gutters and shutters of the greenhouse ${ }^{73}$, but the situation remained disastrous and the pleas of Balsamo Crivelli continued ever more distressed; in response, the Government merely reiterated that any expenses would have to come out of the Garden's ordinary funds ${ }^{74}$.

Notwithstanding the situation of disarray, the Milanese naturalist did not abandon his task of expanding the relations of the Botanic Garden of Brera with other gardens, as evidenced by his report of 1837 listing the exchange of seeds with the botanic gardens of Modena, Monaco, Turin, Bologna and Padua ${ }^{75}$, and also by the epistolary relationship he started with Giovanni de Brignoli di Brunnhoff (1774-1857), director of the Garden of Modena, in the letter dated March 2, 1837, in which he promised to send to the Modenese botanist a packet of seeds that he did not find listed in its catalogue. The seeds were sent only on June 9, $1837^{76}$, because of engagements due to "the handing out of prizes for manufacturing on the name day of our sovereign" organized by the Istituto Lombardo di Scienze, Lettere ed Arti, of which he was a "scholarly" member since 1828 (Della Peruta, 2007). The correspondence between Modena and Milan continued in the subsequent years. In this regard, of particular interest is the letter of Balsamo Crivelli dated July 20, 1840, in which, in exchange for sending several binders of dried moss, he 
asked for "fossil shells from the secondary sedimentary structures of Modena, since geology [had begun to form] part of [his] favourite studies" 77 . This was perhaps the first sign of a gradual loss of interest in botany, which was not separate from, but indeed probably partly caused by, the numerous, unsuccessful attempts to improve the disastrous situation of the Garden, and by the low salary he received. In fact, even after so many years, he was still officially a substitute professor earning a salary of 480 florins per year rather than the 800 florins of a provisional professor $^{78}$. Balsamo Crivelli's new interest in geology was reiterated in letters dated August 24, 1840, in which he asked Brignoli for fossils from secondary sedimentary structures, and March 5, 1841, where he wrote, verbatim: "I made a trip to Valgana and collected many fossils. I did not collect plants because mineralogy and geology are my main occupation. I cannot assure you of being able to send the plants you asked me, because I am in negotiations with a friend of mine from Innsbruck to exchange them with rocks and fossils of the Tyrol"79. Confirming the new direction taken by the studies of Balsamo Crivelli are two lists of land and river shells - dated August 1838 and March $1839^{80}$ - sent him by to Antonio and Giovanni Battista Villa, two Milanese collectors linked to the Museo di Storia Naturale, of which Balsamo Crivelli was appointed a judicial depositary in June 1838, with the task of curating the collections (Conci, 1967: 30). His diminished interest in botany and growing attraction with geology - which earned the Milanese naturalist a diploma from the Société Géologique de France, as evidenced by the letter dated July 5, 1840, sent by the new director of the Liceo di Sant'Alessandro, Ferdinando de Herra ${ }^{81}$ - had been also accompanied in the meanwhile by an interest in veterinary science, a discipline in which he graduated in 1837 (Taramelli, 1883: 10; Conci, 1967: 36). His knowledge of zoology later allowed him to draw up the wildlife prospectus for Notizie naturali e civili su la Lombardia (Bernardoni, Milan, 1844) by Carlo Cattaneo, published on the occasion of the Sixth Congress of Italian Scientists, held in Milan in September $1844^{82}$.

The situation of the Garden continued to worsen to the point that, with the dispatch of September 14, 1837, the General Directorate of Public Constructions instructed the Government to draw up a project for the construction of a new greenhouse for the sum of 47,817.99 lira. The Central Accounting Directorate demanded on December 11 the specifics of the work and the conditions of contract $^{83}$. The project remained on the drawing board for many years, and the pleas of Balsamo Crivelli continued ever-more insistent. But the Milanese naturalist managed to get only the ruined steps of the ponds repaired and paid for as an item placed in the extraordinary funds ${ }^{84}$. Subsequently, in the hope of attaining additional benefits, he described in a letter dated April 5, 1838, the condition of the Garden with great precision, clearly explaining that the funds could not cover any outstanding repairs because they were completely absorbed by the expenses for fuel, the purchases of pots and soil, the maintenance of the windows, shutters and wooden structures, and the forwarding of seeds and plants to other botanic gardens ${ }^{85}$. This time, he managed to obtain, with the governmental authorisation of November 16, 1838, the restructuring of the loggings of the gardener and assistant ${ }^{86}$. He was also granted the construction of a canopy for the protection of the most important vases against hail: the work, deliberated in the governmental assembly of June 21, $1839^{87}$, and then approved on July 11, 1839, by Archduke Ranieri ${ }^{88}$, was carried out for the sum total of 3,000 lira, as evidenced by the minutes of the governmental assembly of September 23, 1842.

As for the problems related to the chair of natural history, they were only partially resolved. In fact, the Aulic Commission for Studies communicated to the Government on May 9, 1838, that "the establishment of a professorship in natural history at the two licei [would not have been] authorised, but at the same time did permit that the current, provisional holder of the position, Balsamo Crivelli, [would have] his annual allowance increased to eight hundred florins" $"$.

The aspiration of the Milanese naturalist to a permanent position was, thus, frustrated. However, work continued in the Garden, even if accompanied by a mood of despondency, as emerges from a letter sent October 3, 1838, to Robert De Visiani, Prefect of the Botanic Garden of Padua, in which Balsamo Crivelli asked - after having notified the Paduan botanist that he had prepared for him a case of ornamental plants, including a rare Stapelia europaea - for some plants for his "miserable establishment", adding: "I say miserable given the poor state of the greenhouse and many other circumstances...."90.

The conditions of the greenhouse at that time is attested also by the testimony of the Milanese explorer-naturalist Antonio Raimondi (1824-1890), who, before leaving for Peru, witnessed the death of an exotic plant, probably due to the cold, during one of his frequent visits to the Garden. This is his description: "One day, finding myself, as usual, in the greenhouse of the Botanic Garden of Milan, I was present at the cutting of a giant peruvianius Cactus (Cereus repandus (L.) Mill.), which rose up like a monstrous candelabra to the roof, along most of which it grew supported by ropes. The mutilation of that patriarch of the cacti, one of my favourite plants, caused me a vague regret as if it were an animate and sensitive being, and that strange circumstance gave birth within me of a sympathy for its native Peru"(Janni, 1940: 29-30).

Meanwhile, the budget of the Garden continued in the red because the most urgent repair works to prevent the collapse of the greenhouse were being increasingly covered with the regular funds, as demonstrated by the minutes of the governmental assembly of May 25, $1840^{91}$.

Then, driven in all likelihood by a lack of gratification with the Garden, Balsamo Crivelli began accepting other commitments he was receiving on account of the fame he had achieved as a naturalist. In 1840, he was appointed senior member of the Istituto di Scienze, Lettere ed Arti because of his organisational work at its library (Della Peruta, 2007) as well as, as we have seen, for his assignment of prizes for manufacturing. The following year, he was elected to the Collegio dei Conservatori of the Museo di Storia Naturale, a body set up by the 
Municipality, with a mandate to oversee everything concerning its development and progress (Conci, 1967, 36 and 49). However, these commitments distracted him from the Garden only in part, as evidenced by a letter he wrote on February 3, 1842, to Giuseppe Moris (17961869), professor of botany and director of the Botanic Garden of Turin, in which he voiced his intention to keep taking care of the Garden of Brera, while lamenting the inability of the now old gardener and assistant; he continued saying that he would reorganise the collection of seeds in order to send him some in exchange for those he had received; and finally enclosed a list of exotic and ornamental plants and seeds wanted for the Garden ${ }^{92}$.

He was still devoting himself to the Garden in January 1844, when he announced to Ferdinando de Herra, the new director of the Liceo di Sant'Alessandro, that he had noticed that the adjacent wood, because of its position and growth, had created a shadow that was harmful for the greenhouse, and therefore proposed to eradicate it, transplanting the trees to the eastern side of the Garden ${ }^{93}$. $\mathrm{He}$ also wanted to buy new conifers to plant along the Garden's northern wall, since they would have been useful for educational purposes, and to uproot uninteresting trees on the southern side, replacing them with shrubs that would be more instructive. This required the felling of 110 trees and the acquisition of 200 trees and shrubs, for a total cost of 563,50 lira, from which could be deducted the costs of purchasing fuel for an entire year, since the felled trees would serve for the heating of the greenhouse. The letter ended with a plea for intercession with the Government so that "[it might approve] the execution of the mentioned tasks, which [would make] the garden more suitable for the visits of scientists in the coming September"94. The proposal was approved by the Government on September 9, $1844^{95}$, after Balsamo Crivelli had already done the work, as evidenced by the following words with which Giuseppe Sacchi (1844) commented the visit of scientists participating at the Congress of Milan: "The large trees damaging the heater on account of their excessive shade, or that were shrivelled by old age, were almost all felled this year and replaced with a new and more selected plantation and the addition of new species not before possessed". To this initiative was added the restoration of the external walls, the cold boxes, the walkways around the ponds, and the ponds themselves, for a total cost of 322 lira. The work, given the imminence of the Congress, were quickly carried out by the Directorate General of Public Constructions which, upon finishing, asked the Government for payment. It was decided that the expenditure could be loaded onto the funds for the preservation of Brera Building ${ }^{96}$.

Less fortunate was the initiative taken in 1845 with the consent of de Herra, Giovanni Labus and Gabrio Piola - the latter two respectively president and vicepresident of the Istituto Lombardo di Scienze, Lettere ed Arti - (Della Peruta, 2007) to derive a channel from the nearby Martesana Canal that would on the one hand allow to conduct hydraulic experiments with the institute's machines, and on the other to "water the Botanic Garden, for which it [had] great need, having actually to make use of spring water that [had become] extremely expensive for those people who [used] it for this purpose and which [was] not the most suitable for vegetation and special crops" "97. However, the Board of Constructions did not recognize the utility of the project, and considered the planned expenditure of over 17,000 lira, plus the outlay for maintenance, to be excessive ${ }^{98}$.

Balsamo Crivelli's commitment to the Garden was also manifested at the death of the gardener Giacomo Seveso, on December 28, 1845. The Milanese naturalist wrote the following day to de Herra, recommending that the notice announcing the competition for the post of gardener declare that, according to the regulation, he must work personally at the Garden and not just give orders to the assistant. He also added that it would be appropriate that the appointment become permanent only after a year's test period ${ }^{99}$. On April 29, 1846, as requested by Balsamo Crivelli, Gaspare Pecorara was appointed gardener on a provisional basis. $\mathrm{He}$ had been a "gardener-cultivator and landscaper for various Milanese lords". After the trial period, his position was finally confirmed on June $19,1846^{100}$.

The problems with the greenhouse continued to remain unresolved, and in 1846 the Milanese naturalist repeated his proposal that it be rebuilt on the basis of Caimi's 1833 plans, but with the addition of an innovative and much cheaper heating system ${ }^{101}$. The Government did not take a decision, and Balsamo Crivelli was forced, once again, to limit himself to undertaking only the most urgent repairs, specifying that they were to be borne by the Tax Administration ${ }^{102}$. But Deputy Johann Baptist Spaur, appointed in Milan in May 1841, replied with a dispatch on October 23, 1846, that those costs would have to be paid with the annual funds allocated to the Garden and could not be considered as an extraordinary expense, also advising "to limit the expences to indispensable works while [awaiting] the project for the complete renewal of the greenhouse"103. However, this remained on the drawing board while, as in previous years, a deficit in the balance sheet of the ordinary funds of the Garden was created and destined to continue.

Despite these endless worries, the Milanese naturalist, together with the help of Pecorara, took time that year to compile the requested list of the Garden's potted plants, which were apparently considered to be of greatest interest. The list, which we reproduce in the Appendix, indicates a high prevalence of aesthetic-ornamental plants, and suggests that - due to the lack of importance assigned by the Austrian Government, as mentioned above, to the teaching of botany at the Garden - it had become to function increasingly as a reference point for amateurs of rare and decorative plants in Milan. Balsamo Crivelli's idea was that this would represent a first step in the preparation of a catalogue. However, he would never complete the catalogue on account of multiple commitments that - as we will see - would burden him later. He obtained a better result with the translation of $A$. de Jussieu's Botanique, by A. de Jussieu, part of Cours élémentaire d'Histoire Naturelle by A. de Jussieu, H. Milne Edwards and F. S. Beudant (Langlois et Leclercq, Paris, undated), which Balsamo Crivelli published in 1846, adding some notes and an appendix on Italian flora. 
Meanwhile, Mauro Volpi ceased his activities as assistant gardener on August 29, 1847, and was succeeded by Giuseppe Bernardoni ${ }^{104}$. But the later was fired one year later ${ }^{105}$ and replaced, after various vicissitudes, by Giuseppe Riva, who took possession of his loggings only upon the eviction of Bernardoni, who refused to leave ${ }^{106}$. However, the training of Pecorara proved difficult: initially, he could scarcely fulfil his duties to work personally at the Garden: he and limited himself to oversee the work of the assistant ${ }^{107}$ and revealed himself also to be "inexperienced in the cultivation of plants in botanic gardens" 108 . Considering the difficult general state of the Garden, this fact was not irrelevant for Balsamo Crivelli. Compounding these difficulties further was his assignment as provisional director of the Museo di Storia Naturale in September 1848 - which would last until August 1849 (Conci, 1967: 36) - upon the proposal of the Municipality of Milan. He took over from Jan, who had left the city after the return of the Austrians driven out by the revolutionary movement in August 1848. This would prove to be a weighty task for Balsamo Crivelli, as he explained on September 23, 1848, to Emilio Cornalia, friend and future director of the museum, but he had felt he was unable to refuse $\mathrm{it}^{109}$. Throughout this period, Balsamo Crivelli remained in contact with Jan, informing him of the situation of the licei, which had been closed by the Austrians for a few months - as he wrote in his letters of November 2 and December 11, 1848, and January 19 and February 13, 1849 - due to the insurgency; of the exchange of plants carried out for the benefit of the Museo di Storia Naturale with De Notaris, in the letters of January 11 and May 23, 1849; and of his new interest in myriapods, as evidenced by his letter of April 8, $1849^{110}$. Regarding the later, he had collected many myriapods of the genus Julus in the Garden ${ }^{111}$. This new interest would lead to the publication of Di alcune specie di miriapodi del genere Julus e di alcune loro particolarità (Bernardoni, Milano, 1862). He also resumed his correspondence with Moris, as evidenced by his letter of February 27, 1850, in which he thanked his friend for sending the seed catalogue of the Garden of Turino, and gave him a wish list of things needed for his new position as professor of botany to first-year private student of medicine ${ }^{112}$.

Finally, after many pleas, he received the long-awaited news that the Government had agreed to include in the 1852 budget the sum necessary for the total reconstruction of the greenhouse as set out in the 1837 project $^{113}$. The resolution - which remained only on paper until 1855 , as we shall see ${ }^{114}$ - was made thanks to a greater importance given by the Austrians to the study of natural history, as set out in the New Plan for Philosophical Studies in the Kingdom of Lombardy-Venetia. Along with the circular of October 2, 1851 (Bollettino Provinciale, Puntata XXVI, 1851), this plan specified that licei and ginnasi were to be united and placed under a single management starting from the 1851-52 academic year; moreover, with the notification of October 23, 1851 (Bollettino Provinciale, Puntata XVIII, 1851), it was determined that the teaching of natural history would be extended also to the ginnasi, increasing the number of hours of the subject from four per week for licei, as had been set out in the Study Plan of October 30, 1824 (Raccolta degli Atti del Governo, 1825), to a total of fourteen, to be divided among the I, II, III, V and VI classes, without changes, however, in the educational content of the discipline.

But by now, Balsamo Crivelli was distancing himself from the management of the Garden. In 1850 he was elected vice-president of the Istituto di Scienze, Lettere ed Arti (Della Peruta, 2007) and in 1852 was called to the chair of mineralogy and zoology at the University of Pavia (Gliozzi, 1963).

He left the Garden of Brera a rich herbarium from the Milanese area in seven packages, a herbarium of plants cultivated from 17 types of centelles (Centella spp.), three othersmallherbariaaccompaniedbycatalogues ofabouttwo thousand species ${ }^{115}$; and books, including a copy of Genera plantarum and of Linnaeus' Systema vegetabilium, edited by Kurt Sprengel (Gottingae, Sumptibus Dietrichianis, respectively 1830-1831 and 1825-1828); a copy of L'art de cultiver les jardins, ou annuaire du bon jardinier et de l'agronome by Charles-François Bailly de Merlieux (Librairie Encyclopédique de Roret, Paris, 1831); a copy of Anleitung zur Pflanzenkenntniss nach Linné's Methode. Zum Gebrauche der Vorlesungen an der Universität by Nikolaus Joseph Jacquin (Wappler und Beck, Wien, 1800); a copy of Summa plantarum quae hactenus innotuerunt methodo linneano per genera et species digesta illustrata descripta by Fulgenzio Vitman (Typis Imperialis Monasterii S. Ambrosii Majoris, Mediolani, 1789-1792); a copy of the Tavole analitico-elementari di botanica con annotazioni by Giuseppe Bayle-Barelle (Stamperia del Giornale Italico, Milano, 1804); and other systemic tables, catalogues and manuscripts.

\section{Vincenzo Masserotti and Giustino Arpesani: the controversial construction of the new greenhouses and the concession of the Garden of Brera to the Istituto Tecnico Superiore}

Following the appointment of Balsamo Crivelli to Pavia, Vincenzo Masserotti (?-1875) was appointed professor and deputy director of natural history of the two licei (Anonymous, 1933; Sordelli, 1875). After obtaining his degree in medicine, surgery and obstetrics at the University of Pavia in 1841, Masserotti practiced medicine along with the study of natural history, as evidenced by his translations of Minéralogie by F. S. Beudant (Langlois et Leclercq, Paris, undated) and Premiers éléments De Chimie by H. V. Regnault (Langlois et Leclercq, Paris, 1850). In 1851, the year of his appointment as a professor of natural history at the licei, he began publication of his Italian versions, with notes and additions, of Cours d'Histoire Naturelle by H. Milne Edwards and A. Comte (Meline, Cans et Compagnie, Bruxelles, 1840), and Traité élémentaire de Physique expérimentale et appliquée et de Metéorologie by A. Ganot (Chez l'Auteur, Paris, 1854), which he translated with Camillo Hajeck, professor of physics at the Liceo di Sant'Alessandro.

From the outset, Masserotti was worthy of the position because of his "success in teaching" 116 , which he organised as follows ${ }^{117}$ : in the first class he taught zoology, using Compendio di Storia Naturale by S. C. Fischer (I.R. 
Stamperia, Milano, 1842); in the second class, he taught zoology, with Fischer's compendium, and botany, using Storia Naturale delle piante ad uso dei Ginnasi e delle Scuole Reali Inferiori dell'Impero Austro-Ungarico by A. Pokorny (Mechitaristica, Vienna, 1854); in the third class, he taught mineralogy, using Fischer's compendium and Elementi di Storia Naturale per uso dei Ginnasi e delle Scuole Tecniche Superiori delle Provincie AustroUngariche: Mineralogia, by R. Molin (Gerold, Vienna, 1852); in the fifth, he taught systematic natural history and mineralogy, using Corso Elementare di Storia Naturale: ad uso dei Licei e degli Istituti di Educazione, by $\mathrm{H}$. Milne Edwards, A. de Jussieu, F. S. Beudant (Vallardi, Milano, 1846); in the sixth he tought systematic natural history using Corso elementare, by H. Milne Edwards, A. de Jussieu, F. S. Beudant, and Elementi di Zoologia per uso degli I. R. Ginnasi Superiori by L. K. Schmarda (Gerold, Vienna, 1854).

During his directorship of the Garden, the event with greatest importance was undoubtedly the construction of two new greenhouses in place of the old one, which was finally carried out in the winter of 1855-1856 $6^{118}$. Before the building work could be started, the plants were moved to other areas of Brera Building and to locally owned premises of the gardener, Pecorara, which he placed at the disposal of the Garden, saving about a thousand specimens from the cold. As for the flower beds - which were planted in the Garden in 1854 as a result of the greater emphasis placed on natural history by the New Plan for Philosophical Studies of 1851, mentioned above - they required a significant increase in care; however, the work carried out was not enough to prevent the death of many of them ${ }^{119}$.

The official architect Luigi Voghera was instructed to supervise the construction of the two greenhouses: an upper one and a semi-interred one, called the subterranean greenhouse, on the basis of the project developed by the Directorate of Public Constructions in 1837. However, the original building plans were altered with changes and additions dictated not only by the progress that had been made in the meanwhile in botany, but also by the "many needs" that the project of the Directorate of Public Constructions had not foreseen ${ }^{120}$, all of which led to a significant increase in costs ${ }^{121}$. To justify this increase, Masserotti stated in his letter to Antonio Odescalchi, the new director of the Liceo di Sant'Alessandro, that the changes and additions were absolutely necessary, and, in particular, that it was "essential to give greater width and height to the new greenhouse, the old project not having allocated enough space for the shelter of the increased number and size of the plants" and adding that "it was a shame that the curve given to the ceiling [would not have] allowed what was necessary for the elevation of the rear part" and also that "the distancing of the cold frames from the body of the greenhouse was also absolutely indispensable to make the exterior of the large windows accessible, and the new building would have missed an accessory which it could not do without if it were constructed without a porch under which soil and compost could be prepared and vases could be kept during the operations necessary for changing the soil and for the new plantations"; and finally that "this new greenhouse would result imperfect and insufficient for its intended purpose if one could not use one of its wings to deposit the herbaria and the books needed for education in a room suitable also for the microscope for the observations and demonstrations that the professor must conduct on the site". Therefore, he requested that the additional costs were approved by the higher authorities ${ }^{122}$. The answer came from the new deputy, Friedrich Moritz von Burger, in his dispatch to the Directorate of Public Constructions of February18, 1856, in which he declared himself opposed to an amnesty of the additional costs, justifying his decision with the fact that Voghera had not been allowed to change the project approved by the Ministry of Education, and pointed out some defects in the changes made, asking that they were removed or at least reduced. To arrive at a final clarification, he proposed the formation of a commission to visit the greenhouses, consisting of Professor Santo Garovaglio of Pavia, an employee of the Directorate of Public Constructions, Masserotti, Deputy Secretary Ferdinand Besozzi - acting Director General of Ginnasi - and Voghera himself ${ }^{123}$.

Pending the opinion of the commission, Odesclachi was forced already in that year to apply to the DirectorateGeneral of Ginnasi for an increase of 800 lira in the ordinary funds of the Garden, justifying the request with the doubled capacity of the new greenhouses and the increased costs for fuel that this entailed; the greater extension of the cultivated part of the Garden, caused by the felling of the trees that had previously served to conceal the state of decay of the old greenhouse; and the resulting increase in costs for the purchase of vases, tags, posts, glass bells, lubricants, painting of the shutters and repairs to the windows ${ }^{124}$. The request was repeated the following year ${ }^{125}$, but the deputy secretary made it known that the budget would not be increased. Odescalchi then returned to urge the Ministry of Religion and Public Education, stating that he would not take responsibility for the possible death of the plants ${ }^{126}$. Less than a year later, on September 22, 1858, having received no reply, he went back to the Lombard Deputy Secretary, warning that there was a need to repair the shutters of the subterranean greenhouse, whose frames were defective, and that the costs were not sustainable with the ordinary funds ${ }^{127}$. After just a few months, he returned to inform the Deputy Secretary of the need to repair the main greenhouse's heater and pipes, and the wooden stands for the vases ${ }^{128}$. The Government's response came at last, but was categorically negative ${ }^{129}$. The Garden was plainly not a matter of interest for the Austrians any more. Their concerns were directed elsewhere. There was an imminent danger of war, the Piedemonteses army was mobilising and volunteers were flocking from every part of the Italian peninsula. In May, the Franco-Piedemonteses began their march towards Lombardy and, after beating the Austrians on several occasions, entered victorious into Milan on June 8; on November 10, the annexation of Lombardy to Kingdom of Sardinia was decreed by the Treaty of Zurich. Just three days later, the law of November 13 on the restructuring of public education, known as the Casati Law (Atti del Governo, 1859), reduced the importance of the teaching 
of natural history, which would no longer be part of the curriculum of the ginnasi, but only of the licei. As a result, it was feared that the new Government would not consider the importance of the Garden any more than had done the previous. Masserotti drafted a detailed report on the role of the Garden, underlining its 4,000 plant species arranged according to the systems of Linnaeus and Jussieu, the existence of two, still "very imperfect" greenhouses, two cold boxes, a seed-bed and a classroom equipped with a natural-light microscope, and drawing attention also to the fact that the Garden was used by two licei, as well as the School of Santa Marta and the Technical School, and had been for nearly a century an ornament of the city of Milan admired by many students of botany; he concluded with a request for an increase in the ordinary funds as well as the allocation of the money needed for repairs in particular to the subterranean greenhouse ${ }^{130}$. It was the last, futile plea of Masserotti. With the Ministerial Decree of September 30, 1860 ${ }^{131}$, Giustino Arpesani (1817-?) was appointed professor of natural history at the two licei and director of the Garden: he had graduated in medicine and surgery, and had been under the employment of the Museo Civico di Storia Naturale for five years, then professor of chemistry and natural history at the Scuola Tecnica of Milan and finally professor of natural history at the Collegio of Casale. As for his scientific output, he had co-authored with Francesco Selmi the Italian edition with notes and additions of H. V. Regnault's Cours élémentaire de Chimie (Masson, Langlois et Leclerque, Paris, 1851), and with Giuseppe Balsamo Crivelli and Carlo Porro he had translated, with notes and additions, F. S. Beudant's Géologie (Langlois et Leclercq Masson, Paris, 1840) ${ }^{132}$. As soon as he took office as director of the Garden, Arpesani immediately set to work with great zeal, managing to convince the governmental authorities not just to pay only a part of the debts of the Garden, which had accumulated over the years, but to liquidate them entirely ${ }^{133}$; he also obtained the appointment of a new assistant gardener, Carlo Slavazza ${ }^{134}$. Shortly after, was able to conduct, with the support of the dean of the Liceo di Sant'Alessandro, Francesco Tagliabue, some maintenance and renovation work in the Garden: these included the construction of walls surrounding the ponds and repairs to the cold frames ${ }^{135}$; repainting work $^{136}$; a heater to improve the heating of the main greenhous $\mathrm{e}^{137}$; a "mechanical system with levers and pulleys and machined extremities to facilitate the opening of the greenhouse's windows"138; and a heater for the interred greenhouse ${ }^{139}$. But the new state was not in favour of the Garden being used as a tool for the teaching of natural history in the licei, as evidenced by two letters from the Minister of Public Education, signed by Quintino Sella, to the Head Department of Education of the Province of Milan, Giulio Carcano, in which it was stated that the final status of the Garden had not yet been decided and that there would therefore be no increase in its funding. A further demonstration of the lack of interest of the new kingdom for the Garden was the visit in May 1861, unbeknownst to Arpesani, of employees of the nearby Academy of Fine Arts and the Public Board of Engeneers to study the possibility of building a school of sculpture on a part of the area of the Garden. Informed of the visit, Arpesani wrote a long letter to Tagliabue, emphasizing that "most serious drawbacks [would result] to the Garden upon the accomplishment of that project" and concluded that "if the Ministry [believed] it absolutely essential to take over part of the area of the Garden, that he [be] informed of the serious damage that [would result] and thus try to inflict the least damage possible"140.

Shortly after, on January 14, 1863, the destiny of the Garden was established conclusively by the Government: in the presence of Cavalier Raffaele Masi - the new dean of the Liceo di Sant'Alessandro - Arpesani, the head gardener Pecorara and the Commendatore Francesco Brioschi - the director of the Istituto Tecnico Superiore - the Istituto Tecnico Superiore was given possession "of the various buildings, the garden, the heater, the annexed rooms, the utility rooms, etc.., the plants, both in pots and in the ground, the herbarium, the seeds, the few botanical works, the natural-light microscope, the various cultivation tools and anything else constituting the abovementioned botanic garden". Shortly after, at the request of Arpesani to the Head Department of Education of the Province of Milan, it was deliberated that the professor of natural history of the Liceo di Sant'Alessandro "[could avail] of the botanic garden for his students"141.

So ended - regardless of this final, modest concession - a long chapter in the history of the Botanic Garden of Brera.

\section{The plants of Balsamo Crivelli: botanical considerations}

The list of plants compiled by Balsamo Crivelli includes 546 specimens, the botanical identification of which is discussed here. A limit to this identification is the fact that Balsamo Crivelli's binomial nomenclature was not accompanied by relative author citations, nor has it been possible to trace a hypothetical reference model for the author. Therefore, the work of transferring his binomens to the current scientific model has been based on two closely related factors: the interpretation of the original handwriting of the author, and verification of the likelihood that the object's identification is correct. Regarding the first point, 10 cases could not been resolved because of the inability to understand the handwriting of the author, either for specific epithets or for the generic name: they sometimes appear sketchy or abbreviated in an incomprehensible fashion, or degraded because of poor conservation of the paper. Regarding the second, 21 Balsamo Crivelli biomens (3.92\% of the total, excluding unread epithets) have readable epithets but are apparently non-existent: in other words, they could not be found in the botanical literature or official databases (International Plant Name Index, Tropicos, The Plant List), indicating that for these the author had not been inspired by completely scientific sources. In some cases, we had the impression that, what seemed to be a (certainly not official) scientific epithet, should be interpreted as a horticultural qualification, i.e., a name assigned to a cultivar to highlight an evident characteristic. The existing, officially documented binomens have given rise to four different results: 
1. confirmation of the Balsamo Crivelli binomen (sometimes corrected for spelling) in line with the current nomenclature;

2. confirmation of the taxon ranked below the binomen under the current nomenclature;

3. failure to identify the taxon due to homonymy in the absence of any author citation: in official sources, the same binomen is found under two or more authors (up to 7 in two cases) with differing botanical identity, making it impossible to determine which species Balsamo Crivelli was referring to;

4. lack of identification of the taxon because of indetermination: the binomen creates a series of systematic, taxonomic and typological queries, which, according to what is reported in The Plant List, qualifies the binomen as "unresolved".

On this last point, it is useful to add a few considerations. An unresolved status in The Plant List has several times not corresponded with reality: that is to say, a number of established binomens - without defects in the coherence of typological legitimacy, priority, validity or otherwise were challenged. (((and this despite it warning the user it is an "unresolved name".))) In other cases, especially for the Linnean binomens, the site, which apparently has not been updated with the progresses of The Linnean Plant Name Typification Project, indicates as "unresolved" what instead is a fully resolved binomen. In the most favourable cases, an "unresolved name" is accompanied by a hazard probability suggestive of a possible nomenclature match, but this is almost always for correctly resolved binomens and usually correctly intuitable through experience and common sense. With these limits, we have tried to tackle the critical problems posed by Balsamo Crivelli's list, often deciding differently from that stated in The Plant List, and adopting - on the basis of evidence from elsewhere - the qualification "unresolved name" only for cases deemed to be effectively unsolved or, at least, so devoid of informational bases that it could not be classified otherwise.

\section{The layout of the table}

The species list is given below in a table consisting of three columns: the first gives in alphabetical order the names of the plants as written by Balsamo Crivelli, without changes in his spelling or use of capital letters; the second column gives the current name of the species (binomial or trinomial, with the names of authors abbreviated according to official usage) and also contains the following information:

- Unread epithet: indicating that the specific name is illegible;

- Epithet not found: to indicate that the specific name is absent in the botanical literature;

- Unresolved: $n$ homonyms: for a binomial unresolved due to homonymy, $n$ being the number of homonyms;

- Unresolved (PLK): when a binomial is unresolved due to indeterminability, $P L K=$ according to The Plant List.

The third column gives the families to which the species belong and for which some clarification is needed.
The systematic circumscription of the families and relative nomenclature follows the Reveal \& Chase model (2011), as officially set out in the online site dedicated to angiosperm phylogeny (Stevens 2001 onwards): this site is curated by the Missouri Botanical Garden (Missouri, USA), which collates the results of botanical phylogenetic research. By choice of the editorial committee, many families that in the past were treated as independent taxa have been merged into higher expanded units, always of family rank, and believed useful for educational purposes in that they facilitate learning through the use of shorter names (a problem that is absolutely not confronted by Italian universities, in which plant phylogenetics, systematics and taxonomy are only hinted at, if not completely ignored). However, the concept of family is still officially founded, as a starting point, on the du Jussieu system (1789), which brings together in "ordines" those plants linked by obviously similar morphological traits (flowers and its structure). It seeks to highlight this fact in order to emphasise an important practical (working) aspect of the "ordines" (families), defined by Jussieu himself to facilitate the assignment of a genus to the corresponding family on the basis of a set of shared traits. With the phylogenetic enlargement of families, the working purpose mentioned above is inevitably lost because the similarities in the DNA (the identity of nucleotide sequences) - which undisputedly demonstrate evolutionary kinship (common descent) - do not necessarily lead to morphological similarities. Therefore, an extended family can contain plants without similar morphological traits, and so we see no value from intuitive and educational points of views. In contrast, restricted families - appropriately compiled in accordance with progresses in molecular phylogenetics - exclude most plants devoid of shared characters, making as it were a better service to working research and teaching.

Here, we decided not to deviate from official indications but, at the same time, retrieve the information related to restricted families, highlighting the latter in the subfamily rank. This solution has obviously not been applied to all the Reveal \& Chase (2011) families referred to here, but, in stark contrast to traditional methods, only to those resulting from the most obvious and recent unifications. The families in question are: Amaryllidaceae (= Allioideae + Amaryllidoideae + Agapanthoideae), Asparagaceae $(=$ Agavoideae + Aphyllanthoideae + Asparagoideae + Brodiaeoideae + Lomandroideae + Nolinoideae + Scilloideae), Malvaceae (= Bombacoideae + Brownlowioideae + Byttnerioideae + Dombeyoideae + Grewioideae + Helicteroideae + Malvoideae + Sterculioideae + Tilioideae), Primulaceae (= Maesoideae + Myrsinoideae + Primuloideae + Samoloideae + Theophrastoideae), Scrophulariaceae (= Buddlejoideae + Myoporoideae + Scrophularioideae), Xanthorrhoeaceae (= Asphodeloideae + Hemerocallidoideae + Xanthorrhoeoideae).

\section{Acknowledgements}

We would like to thank all those who supported and helped us during the writing of this paper. In particular: Anna Elisa Ravenna and the staff of the Biblioteca 
Braidense of Milan; Anna Alessandrello of the Museo di Storia Naturale of Milan; Paola Livi and the staff of the Library of the Museo di Storia Naturale of Milano; Mariapia Bortolotti, Marco Lanzini and the staff of the Archivio di Stato of Milan; Giovanna Calati of the Library of the Archivio di Stato of Milano; Paola Ciandrini and the staff of the Archivio Storico, Politecnico of Milano; Maria Antonia Conte of the Archivio del Liceo Classico Statale Cesare Beccaria of Milan, Marco Meriggi of the State Univesity of Neaples, Luisa Erba and Alessandra Ferraresi of the State University of Pavia; Giuseppe Olmi of the State University of Bologna, Mauro Guolo of the Library of Biologia Vegetale, Dipartimento di Scienze della Vita e Biologia dei Sistemi, State University of Turin for sending us an original letter of Balsamo Crivelli to Giuseppe Moris; Marta Mazzanti for sending us unpublished documents of Giuseppe Balsamo Crivelli to Giovanni de Brignoli di Brunnhoff kept at the Autografoteca Botanica, Garden of the State University of Modena; and Andrea Callegaro of the Library of the Botanic Garden of the State University of Padova for sending us a letter of Balsamo Crivelli to Roberto De Visiani.

\section{Notes}

${ }^{1}$ Archivio di Stato di Milano (henceforth, ASM), Studi p. m., b. 666.

$2<$ www.lombardiabeniculturali.it/istituzioni/schede/100006/>

${ }^{3}$ ASM, Studi p. m., b. 666.

${ }^{4}$ ASM, Studi p. m., b. 667.

${ }^{5}$ Letter of Saurau to Scopoli dated November 29, 1816 (ASM, Studi p. m., b. 858).

${ }^{6}$ As ascertained from the table of September 30, 1820, giving the list of professors at the Liceo di Sant'Alessandro (ASM, Studi p. m., b. 957).

${ }^{7}$ ASM, Studi p.m., b. 667.

${ }^{8}$ Archivio del Liceo Beccaria di Milano (henceforth, ALBM), b. 21, fasc. 3 .

${ }^{9}$ As per the Government in the letter dated January 10, 1822, to the director of the Liceo di Sant'Alessandro (ALBM, b. 21, fasc. 3).

${ }^{10}$ All three documents at the ASM, Studi p.m., b. 672.

${ }^{11}$ ASM, Studi p. m., b. 861. See also Meneghelli, 1831.

${ }^{12}$ ASM, Studi p. m., b. 672.

${ }^{13}$ ASM, Studi p. m., b. 416.

${ }^{14}$ As per Bignami, Department of Studies, in his letter dated September 12, 1820 (ASM, Studi p.m., b. 672).

${ }^{15}$ ASM. Studi p. m., b. 672.

16 This dispatch is cited in Bignami's letter to the Government, dated August 16, 1823 (ASM, Studi p. m., b. 672).

17 Nominated on October 23, 1821, after the death of Bignami (ASM, Studi p. m., b. 861).

${ }^{18}$ ASM, Studi p. m., b. 672.

${ }^{19}$ See his letter to the Government, dated September 9, 1825 (ALBM, b. 30, fasc. 9).

${ }^{20}$ ASM, Studi p. m., b. 672.

${ }^{21}$ ALBM, b. 76, fasc. 1.

${ }^{22}$ As per the Sovereign Resolution of November 9, 1816 (ASM, Studi p. m., b. 667), in which it is specified that the correspondence between the directors of the licei and the
Government be mediated by the delegates of the Superior Provincial Directorate of Licei.

${ }^{23}$ See dispatch of Bazetta to Frapolli of October 10, 1822 (ALBM, b. 76, fasc. 1).

${ }^{24}$ As per d'Adda to Frapolli in his letter dated November 23, 1821 (ASM, Studi p. m., b. 671). For Ermenegildo Pini and his collection, see Visconti, 2008 and references therein.

${ }^{25}$ As per the Government Commission in its dispatch of June 11, 1823 (ASM, Studi p. m., b. 671). For the policies of Vienna with regard to natural history collections, see also the letter from the Government to Frapolli, dated August 25, 1823 (ALBM, b. 21, fasc. 3).

${ }^{26}$ Dispatch of the Study Commission of Vienna to the Government (ASM, Studi p. m., b. 671).

${ }^{27}$ See the letter dated July 21, 1826, of the then-future director of the Garden, Giuseppe Balsamo Crivelli, to the Milanese naturalist Giuseppe De Cristoforis [Biblioteca del Museo di Storia Naturale di Milano (henceforth, BMSNM), Fondo De Cristoforis, b. 1, fasc. 4)].

${ }^{28}$ See the letter of d'Adda to the Office for the Distribution of Public Funds, dated October 16, 1822, in which he wrote that Bodei died that day (ASM, Studi p. m., b. 857).

${ }^{29} \mathrm{He}$ started work on November 5, 1822, as stated in the minutes sent by Frapolli to the Government (ALBM, b. 30 , fasc. 9).

${ }^{30}$ Prospectus of the Liceo di Porta Nuova for the academic year 1822-1823 (ASM, Studi p. m., b. 667).

${ }^{31}$ See the letter of d'Adda to Frapolli, dated November 20, 1824 (ASM, Studi p. m., b. 668).

32 Prospectus of the Liceo di Sant'Alessandro for the academic year 1824-1825 (ASM, Studi p. m., b. 675).

33 See the dispatch of the Aulic Commission to the Government, dated February 8, 1823 (ASM, Studi p. m., b. 669).

${ }^{34}$ ALBM, b. 76, fasc. 1 .

${ }^{35}$ As per the letter sent October 6, 1834, by the Directorate General of Public Constructions to the Government (ASM, Studi p. m., b. 845). Instead of Gilardoni, the letter erroneously indicates the architect Caimi, who, as we will see, was appointed only in 1830 .

${ }^{36}$ As evidenced in the letter sent November 16, 1830, by the Directorate General of Public Constructions to the Government (ASM, Studi p. m., b. 845).

${ }^{37}$ ASM, Studi p. m., b. 672.

${ }^{38}$ There were not yet technical schools in Milan at the time. The first was founded by Sovereign Resolution in August 12, 1838, and started courses in the 1841-1842 academic year (Romani, 1960).

${ }^{39}$ Archivio generale di Ateneeo, Politecnico di Milano (henceforth, AGAP), Segreteria, titolo XI, b. 85, fasc. R.O.B.

${ }^{40}$ As per the letter sent December 18, 1827 to the Government by the acting director of the Liceo di Sant'Alessandro, Paolo Brambilla, who was temporarily substituting Frapolli (ALBM, b. 30, fasc. 9).

${ }^{41}$ As per the letter of Frapolli to the Government, dated December 1, 1826 (ASM, Studi p. m., b. 858).

${ }^{42}$ See letter of the Government to the director of the Liceo di Sant'Alessandro (ALBM, b. 21, fasc. 3).

${ }^{43}$ ASM, Autografi, b. 110, fasc. 13. 
${ }^{44}$ See the letters of Balsamo Crivelli to De Cristoforis dated July 21, 1826, March 24, 1827, and February 5, 1829 (BMSNM, Fondo De Cristoforis, b. 1, fasc. 4).

${ }^{45}$ As per the letter of Frapolli to Balsamo Crivelli in his letter dated March 6, 1827 (ALBM, b. 30, fasc. 9). The invitation was sent also to Acerbi, who was substituting Balsamo Crivelli that year.

${ }^{46}$ ALBM, b. 62, fasc. 3.

${ }^{47}$ The list is kept at AGAP, Segreteria, Titolo XI, b. 85, fasc. R.O.B.

${ }^{48}$ ALBM, b. 21, fasc. 4.

${ }^{49}$ As per the reply of the Government to Frapolli, dated May 10, 1828 (ALB, b. 21, fasc. 3).

${ }^{50}$ As per the letter of June 10,1828, sent by d'Adda to Gabrio Casati, who took the place of Frapolli between February and December 1828 (ALBM, b. 21, fasc. 3).

${ }^{51}$ For Gilardoni's investiture, see the letter sent him by the Directorate of Public Constructions on April 27, 1829; Caimi's appointment is evidenced by his letter of July 14, 1830, to the Directorate; for the date of the end of the building work, see the report of the architect Bareggi, dated August 31, 1831. All three documents kept at ASM, Genio civile, b. 2803.

${ }^{52}$ Note of Balsamo Crivelli (ALBM, b. 58, fasc. 1).

${ }^{53}$ As per the letter of Balsamo Crivelli to Frapolli dated January 11, 1830 (ALBM, b. 21, fasc. 4).

${ }^{54}$ ALBM, b. 58, fasc. 1.

${ }^{55}$ See his letters to Frapolli, dated March 23and September 7, 1830 (both at the ALBM, b. 58, fasc. 1).

${ }^{56}$ As per the dispatch of the Directorate General of Public Constructions to the Government, dated November 16, 1830 (ASM, Studi p. m., b. 845).

${ }^{57}$ As per the dispatch of the Directorate dated October 12, 1830, communicating the report of Caimi to the Government (ASM, Studi p. m., b. 845).

${ }^{58}$ Confirmed by Sacchi, 1844.

${ }^{59}$ ALBM, b. 58, fasc. 1.

${ }^{60}$ For his role in Austrian Lombardy, see Meriggi, 1987: 93-96.

${ }^{61}$ As per the letter of the Government to Frapolli, dated December 9, 1831 (ALBM, b. 58, fasc. 1).

${ }^{62}$ ALBM, b. 58, fasc. 1.

${ }^{63}$ As understood from the dispatch of January 10, 1833, sent by the Directorate General of Public Constructions to the Government (ASM, Studi p. m., b. 845).

${ }^{64}$ The letter is dated April 4, 1831 (BMSNM, Fondo Jan, b 1, fasc. 9).

${ }^{65}$ As per the letter of Casati to the Government, dated November 19, 1831 (ALBM, b. 30, fasc. 9).

${ }^{66}$ As per the letter of Hartig to Casati of December 3, 1831 (ALBM, b. 30, fasc. 9).

${ }^{67}$ As understood from the letter of Hartig to Casati of December 31, 1831 (ALBM, b. 30, fasc. 9).

${ }^{68}$ As per the letter of Frapolli to the Government, dated April 17, 1833 (ASM, Studi p. m., b. 858).

${ }^{69}$ As understood by his letter to Frapolli of June 3, 1833 (ALBM, b. 30, fasc. 9).

${ }^{70}$ All three letters at the BMSNM, Fondo Jan, b. 1, fasc. 9.

${ }^{71}$ As per the letter of the acting director of the Liceo di Sant'Alessandro, Paolo Brambilla, to Balsamo Crivelli, dated October 7, 1833 (ALBM, b. 62, fasc. 3).
${ }^{72}$ As understood from the dispatch of October 6, 1834, of the Directorate General of Public Constructions to the Government. The document is kept, along with the following two, at the ASM, Studi p. m., b. 845.

${ }^{73}$ As understood from the letter of Brambilla to the contractor Ajmetti, dated January 23, 1836, and from the dispatch of the Directorate General of Public Constructions to Brambilla, dated February 23, 1836 (both documents kept at ALBM, b. 62, fasc. 2).

${ }^{74}$ As per the letter of the Government to the Board of Central Accounting dated May 27, 1836 (ASM, Istruzione Pubblica, b. 35).

${ }^{75}$ ALBM, b. 62, fasc. 4.

${ }^{76}$ Both documents at the Autografoteca Botanica dell'Orto dell'Università di Modena (henceforth, ABOUM), Manuscripts of Brignoli di Brunnhoff.

${ }^{77}$ ABOUM, Manuscripts of Brignoli di Brunnhoff.

${ }^{78}$ As per the letter of the new director of the Liceo di Sant'Alessandro, Ferdinando de Herra, to the Government, dated August 24, 1837 (ALBM, b. 30, fasc. 9).

79 Both documents at the ABOUM, Manuscripts of Brignoli di Brunnhoff.

${ }^{80}$ Both documents at the BMSNM, Fondo Villa, b. 1, fasc. 22.

${ }^{81}$ ALBM, b. 30, fasc. 9.

${ }^{82}$ The scientific congresses were held between 1839 and 1847 at various cities of the Italian peninsula. They were an important and stimulating occasion for Italian scientists to meet and bring to light a unifying Italian scientific culture. For discussions, see Pancaldi (1983).

${ }^{83}$ Both documents at the ASM, Istruzione Pubblica, b. 83, fasc. Orto botanico.

${ }^{84}$ As per the letter of the Government to de Herra, as understood from the dispatch of Archduke Ranieri to the Government, dated June 26, 1838 (ASM, Istruzione Pubblica, b. 127).

${ }^{85}$ As per the letter of Balsamo Crivelli to de Herra of April 5, 1838 (ALBM, b. 62, fasc. 1).

${ }^{86}$ ASM, Istruzione Pubblica, b. 136, fasc. Orto botanico.

${ }^{87}$ ALBM, b. 62, fasc. 4.

88 For this and the following document, see ASM, Istruzione Pubblica, b. 279.

${ }^{89}$ ASM, Istruzione Pubblica, b. 95.

${ }^{90}$ Biblioteca dell'Orto Botanico di Padova, Manuscripts of De Visiani.

${ }^{91}$ ASM, Istruzione Pubblica, b. 182, fasc. Orto botanico.

${ }^{92}$ Biblioteca di Biologia Vegetale dell'Università di Torino (herefore BBVUT), Carteggio Moris.

${ }^{93}$ ALBM, b. 28, fasc. 4. The letter is dated 1843 , evidently an error.

${ }^{94}$ Refers to the $6^{\text {th }}$ Congress of Italian Scientists, mentioned above.

${ }^{95}$ ALB, b. 28, fasc. 4.

${ }^{96}$ As per the letter of the Directorate of Public Constructions to the Government, dated April 5, 1844 (ASM, Istruzione Pubblica, b. 409).

97 As per the letter of the Istituto Lombardo to the Government, dated April 15, 1845 (ALBM, b. 28, fasc. 4).

${ }^{98}$ See his letter dated August 3, 1846, to de Herra (ALBM, b. 54 , fasc. 6 ).

${ }^{99}$ This and the next document are kept at the ALBM, b. 69, fasc. 5. 
${ }^{100}$ AGAP, Segreteria, Titolo XI, b.85, fasc. Pecorara.

${ }^{101}$ As per the letter of de Herra to the Government, dated June 6, 1846 (ALBM, b. 54, fasc. 6).

102 See the letter of de Herra to the Government, dated September 5, 1846 (ALBM, b. 54, fasc. 6).

103 AGAP, Segreteria, Titolo XI, b. 86, fasc. Spese e rimborsi.

104 ASM, Istruzione Pubblica, b. 534, fasc. Volpi e Bernardoni.

${ }^{105}$ As understood from the dispatch of the General Military Intendance to de Herra dated September 18, 1848 (ALBM, b. 68 , fasc. 6$)$.

${ }^{106}$ As per the letter of Balsamo Crivelli to de Herra, dated April 10, 1849 (ALBM, b. 68, fasc. 6).

${ }^{107}$ As understood by the reprimand sent to Pecorara by the Directorate of the Lcei, dated January 14, 1850 (ALBM, b. 68, fasc. 3).

108 As per the letter of Balsamo Crivelli to Moris of February 27, 1850 BBVUT), Carteggio Moris).

${ }^{109}$ BMSNM, Fondo Cornalia, b. 1, fasc. 20.

${ }^{110}$ All letters kept at the BMSNM, Fondo Jan, b. 1, fasc. 9.

111 Letter to Antonio Villa of April 3, 1849 (BMSNM,

Fondo Villa, b. 1, fasc. 22).

112 BBVUT, Carteggio Moris.

113 As per the letter of Deputy Secretary Michele di Strassoldo to the Directorate of the Licei, dated October 12, 1850, (AGAP, Segreteria, Titolo XI, b. 84, fasc. 1850 ).

114 As understood by the dispatch of the Lombardy General Directorate of the Ginnasi e Licei, dated November 23,1855, sent to the Directorate of the Liceo di Sant'Alessandro (ALBM, b. 11, fasc. 3).

115 These herbaria have been lost, as far as can be ascertained.

116 Prospectus of teaching staff for the academic year 1854-1855 (ALBM, b. 13, fasc. 5).

117 Masserotti's teaching programme for natural history for the academic year 1856-1857 (ALBM, b. 42, fasc. 4). The same programme was followed in successive years. ${ }^{118}$ AGAP, Segreteria, Titolo XI, b. 85, fasc. R:O.B.

119 As per the letter of Masserotti to Antonio Odescalchi, new director of the Liceo di Sant'Alessandro, dated February 16, 1856, (AGAP, Segreteria, Titolo XI, b. 85, fasc. Pecorara).

${ }^{120}$ As understood by the dispatch dated July18, 1855, of the Lombardy Directorate of Public Constructions to Odescalchi (AGAP, Segreteria, Titolo XI, b. 84, fasc. 1855).

${ }^{121}$ As understood by the letter of December 8, 1855, sent by the engineer of public constructions Cristoforetti to his directorate (AGAP, Segreteria, Titolo XI, b. 84, fasc. 1855).

${ }^{122}$ AGAP, Segreteria, Titolo XI, b. 84, fasc. 1855.

${ }^{123}$ AGAP, Segreteria, Titolo XI, b. 84, fasc. 1856.

124 The request is dated September 23, 1856 (AGAP, Segreteria, Titolo XI, b. 84, fasc. 1856).

${ }^{125}$ See the letters dated March 23, 1857, and May 11, 1857 , at the AGAP, Segreteria, Titolo XI, b. 84, fasc. 1857.

126 The letter dated November 22, 1857, is addressed to the Ministry of Religion and Public Education (AGAP, Segreteria, Titolo XI, b. 84, fasc. 1857.
${ }^{127}$ AGAP, Segreteria, Titolo XI, b. 84, fasc. 1858.

${ }^{128}$ AGAP, Segreteria, Titolo XI, b. 84, fasc. 1859.

${ }^{129}$ As understood from the prospectus of Masserotti of February 11, 1860, containing a report on the Garden, which will be discussed later (AGAP, Segreteria, Titolo XI, b. 84, fasc. 1860).

${ }^{130}$ AGAP, Segreteria, Titolo XI, b. 84, fasc. 1860. The letter dated February 11, 1860, is cited in Calabrò, 2008.

${ }^{131}$ As understood from the list of the names of the teaching staff at the Liceo di Sant'Alessandro, dated January 19, 1861, (ALBM, b. 13, fasc. 19).

${ }^{132}$ As per the prospectus of the academic year 1866-1867 of the then-ex Liceo di Sant'Alessandro, renamed Liceo Cesare Beccaria after the proclamation of the unity of Italy (ALBM, b. 13, fasc. 8).

${ }^{133}$ See the letters to the dean of the Liceo di Sant'Alessandro, respectively dated December 31, 1860, and July 5, 1861 (AGAP, Segreteria, Titolo XI, b. 84, fascc. 1860 e 1861).

${ }^{134}$ As per the letter of the Inspectorate of Brera Building to the Public Board of Engeneers, dated May 4, 1861 (ASM, Genio civile, b. 6382).

135 As per the receipt of the head builder Domenico Ferradini of January 22, 1861 (ASM, Genio Civile, b. 6382).

${ }^{136}$ As per the letter of August 8, 1861, of the Ministry of Public Education to the Public Board of Engeneers (ASM, Genio civile, b. 6382).

${ }^{137}$ As per the bill of Carlo Da Rossi of September 23, 1861 (ASM, Genio Civile, b. 6382).

${ }^{138}$ As understood from the bill dated November 4, 1861, sent by Carlo De Luigi to the Public Board of Engeneers (ASM, Genio civile, b. 6382).

${ }^{139}$ Bill of Domenico Ferradini dated November 17, 1861 (ASM, Genio civile, b. 6382).

140 The letters from the Ministry of Public Education, dated April 23 and May 11, 1861, and that of Arpesani of August 8, 1861, are kept at the AGAP, Segreteria, Titolo XI, b. 84, fasc. 1861. They are cited by in part by Calabrò, 2008.

${ }^{141}$ Both documents kept at the AGAP, Segreteria, Titolo XI, b. 84, fasc. 1863. Arpesani's request to the Head Department of Education of the Province of Milan is understood from his letter to Brioschi, dated April 13, 1863.

\section{References}

Anonymous, 1933 - Ricordi dei professori lombardi nel secolo scorso, Archivio storico lombardo, 6 (60): 414

Atti del governo di S. M. il re di Sardegna, 1859 - Stamperia reale, Torino, 28 (2): 1903-1988.

Balsamo Crivelli G., 1844 - Fauna. In: Notizie naturali e civili su la Lombardia. Cattaneo C. Bernardoni, Milano: 349-485.

Banfi E. \& Visconti A., 2013 - L'Orto di Brera alla fine della dominazione asburgica e durante l'età napoleonica: i diversi ruoli dei botanici incaricati della sua conduzione e la stesura del primo catalogo. Atti del Museo Civico di Storia Naturale e delle Società Italiana di Scienze Naturali, 154 (2): 173-264. 
Bollettino delle leggi del Regno d'Italia, Stamperia reale, Milano 1811 (2): 1112-1124.

Bollettino provinciale delle Leggi e degli Atti ufficiali per la Lombardia, Puntata XXVI, 1851 (2): 772-773.

Bollettino provinciale delle Leggi e degli Atti ufficiali per la Lombardia, Puntata XXVIII, 1851 (2): 800-806.

Calabrò S., 2008 - Un Orto botanico per la Città di Milano. In: Milano scientifica 1875-1924. Canadelli E. \& Zocchi P. (eds.). Sironi, Milano, 1: 209-233.

Caracciolo A., 1960 - Acerbi, Enrico. In: Dizionario biografico degli italiani. Istituto della Enciclopedia italiana, Roma, 1960, 1: 133.

Conci C., 1967 - Il centenario di Giorgio Jan (1791-1866) e la fondazione ed il primo sviluppo del Museo Civico di Storia Naturale di Milano. Atti della Società Italiana di scienze naturale e del Museo civico di storia $\mathrm{Na}$ turale di Milano. CVI.

Conte M. A., in press - L'Archivio storico del Ginnasio Liceo Beccaria (ex Liceo di Sant'Alessandro).

Della Peruta F., 2007 - Cultura e organizzazione del sapere nella Lombardia dell'Ottocento. L'Istituto Lombardo di Scienze e Lettere dalla fondazione all'unità d'Italia. In: L'Istituto Lombardo Accademia di Scienze e Lettere. Secoli XIX-XX. Robbiati Bianchi A. (ed). Istituto Lombardo accademia di scienze e lettere, Scheiwiller, Milano, 1: 3-492.

Garbari F., 1990 - De Notaris, Giuseppe. In: Dizionario biografico degli italiani. Istituto della Enciclopedia Italiana, Roma, 38: 773-778.

Giglio D. 1978 - I ginnasi e i licei lombardi nell'età della restaurazione. In: Problemi scolastici ed educativi nella Lombardia del primo Ottocento. Ciprandi I., Giglio D. \& Solaro G. SugarCo Edizioni, Milano, 2: 87-192.

Gliozzi M., 1963 - Balsamo Crivelli, Giuseppe. In: Dizionario biografico degli italiani. Istituto della Enciclopedia Italiana, Roma, 5: 621-622.

International Code of Nomenclature for algae, fungi and plants, 2011 July, Melbourne Code (www.iapt-taxon. org/nomen/).

International Plant Name Index (www.ipni.org).

Jussieu de A. L., 1789 - Genera Plantarum secundum ordines naturales disposita juxta methodum in Horto Regio Parisiensi exaratam. Hérissant et Barrois, Paris.

Janni E., 1940 - Vita di Antonio Raimondi. Mondadori, Milano.

Latronico Nicola, 1935 - Enrico Acerbi. La Medicina italiana, Milano.

Le scuole dei barnabiti nel IV centenario dell'approvazione dell'Ordine, 1933 - Numero speciale di Vita nostra: 112.

Memorie e documenti per la storia dell'Università di Pavia e degli uomini più illustri che vi insegnarono, 1878 Successori Bizzoni, Pavia.

Meneghelli A., 1831 - Cenni biografici degli accademici di Padova. Nuovi saggi della Imperial Regia Accademia di Scienze, Lettere ed Arti in Padova, 3: 1-24.

Meriggi M., 1987 - Il Regno Lombardo-Veneto. Utet, Torino.

Österreichisches biographisches Lexicon 1815-1850, 1961 - Johann Baptist Fabian Sebastian Erzherzog von Österrech. Hermann Böhlaus Nachf., Graz- Köln, 3: $122-123$.
Pancaldi G. (ed.), 1983 - I Congressi degli scienziati italiani nell'età del positivismo. CLUEB, Bologna.

Raccolta degli Atti del governo e delle Disposizioni generali emanate dalle diverse autorità, $1817-R$. Stamperia, Milano, 1 (2): 159.

Raccolta degli Atti di governo e delle Disposizioni generali emanate dalle diverse autorità, $1825-R$. Stamperia, Milano, 1 (2): 336-354.

Reveal J. L. \& Chase M. W., 2011 - APG III: Bibliographical Information and Synonymy of Magnoliidae. Phytotaxa 19: 71-134.

Romani M., 1960 - L'economia milanese nell'età della Restaurazione. In: Storia di Milano. Istituto della Enciclopedia italiana, Roma, 14: 675-740.

Rovida C., 1829 - Rettificazione di non pochi errori e inesattezze risguardanti Milano che trovansi nell'opera di Malte Brun. Truffi, Milano.

Sacchi G., 1844 - Istruzione. In: Milano e il suo territorio. Cantù C. (ed). Pirola, Milano: 209-242.

Schivardi A., 1839 - Antonio Bodei. In: Biografia dei medici illustri bresciani. Venturini, Brescia, 1: 125-153.

Sordelli F., 1875 - Seduta 25 luglio 1875. Atti della Società italiana di scienze naturali, 18: 361.

Stevens, P. F., 2001 onwards - Angiosperm Phylogeny (www.mobot.org/MOBOT/research/APweb).

Taramelli T. 1883 - Commemorazione di Giuseppe Balsamo Crivelli. Rendiconti del R. Istituto lombardo, 2 (16): 888-898.

The Linnean Plant Name Typification Project (www.nhm. ac.uk/research-curation/research/projects/linneantypification7).

The Plant List (www.theplantlist.org).

Tropicos (www.tropicos.org).

Villa L., 1956 - I fasti della medicina nell'Ospedale maggiore durante il diciannovesimo secolo. L'Ospedale maggiore, 44 (4):175-179.

Visconti A., 1988 - I 150 anni del Museo Civico di Storia Naturale di Milano. Fusi, Pavia.

Visconti A., 2008 - Scienza, natura e amministrazione del territorio dalla Repubblica cisalpina al Regno d'Italia: il ruolo del barnabita milanese Ermenegildo Pini. In: Istituzioni e cultura in età napoleonica. Brambilla E., Capra C. \& Scotti A. (eds.). Franco Angeli, Milano: 270-295.

Visconti A. 2012 - La fondazione dell'Orto botanico di Brera e gli anni della direzione dell'abate Fulgenzio Vitman (1728-1806) tra assolutismo asburgico ed età napoleonica, Atti della Società Italiana di Scienze $\mathrm{Na}$ turali e del Museo Civico di Storia Naturale di Milano, 153 (1): 27-48. 
Manuscripted list of the Botanic Garden's of Brera potted plants compiled by Giuseppe Balsamo Crivelli in 1846.

(*) possibile denominazione orticola.

\begin{tabular}{|c|c|c|}
\hline Nome secondo Balsamo Crivelli & Identità attuale del taxon & Famiglia \\
\hline Abutilon striatum & Abutilon pictum (Gillies ex Hook.) Walp. & $\begin{array}{l}\text { Malvaceae (subfam. } \\
\text { Malvoideae) }\end{array}$ \\
\hline Acacia acanthocarpa & Mimosa aculeaticarpa Ortega & Fabaceae \\
\hline Acacia "Cascab..." & epiteto non letto $(*)$ & \\
\hline Acacia cornigera & Acacia cornigera (L.) Willd. & Fabaceae \\
\hline Acacia dodonaefolia & Acacia dodonaeifolia (Pers.) Balbis & Fabaceae \\
\hline Acacia eburnea & Vachellia eburnea (L. f.) P.J.H. Hurter \& Mabb. & Fabaceae \\
\hline Acacia falcata & Acacia falcata Willd. & Fabaceae \\
\hline Acacia farnesiana & Vachellia farnesiana Wight \& Arn. & Fabaceae \\
\hline Acacia filicina & Senegalia angustissima (Mill.) Pedley & Fabaceae \\
\hline Acacia floribunda & Acacia floribunda (Vent.) Willd. & Fabaceae \\
\hline Acacia heterophylla & Acacia heterophylla Willd. & Fabaceae \\
\hline Acacia lophantha & Paraserianthes lophantha (Willd.) I.C. Nielsen & Fabaceae \\
\hline Acacia occidentalis & Senegalia occidentalis (Rose) Britton \& Rose & Fabaceae \\
\hline Acacia portoricensis & Zapoteca portoricensis (Jacq.) H.M. Hern. & Fabaceae \\
\hline Acacia rubricaulis & irrisolto (PLK) & \\
\hline Acacia rutaefolia & Acacia nigricans (Labill.) R. Br. & Fabaceae \\
\hline Acacia undulata & irrisolto: 5 omonimi & \\
\hline Achras orientalis & Manilkara zapota (L.) P. Royen & Sapotaceae \\
\hline Achimenes longiflora & Achimenes longiflora DC. & Gesneriaceae \\
\hline Achimenes grandiflora & Achimenes grandiflora (Schiede) DC. & Gesneriaceae \\
\hline Achimenes rosea & Achimenes erecta (Lam.) H.P. Fuchs & Gesneriaceae \\
\hline Acrostichum alcicorne & Platycerium alcicorne (Willemet) Desv. & Polypodiaceae \\
\hline Adelia Acidoton & Flueggea acidoton (L.) G.L. Webster & Phyllanthaceae \\
\hline Aeschynanthus ramosissima & Aeschynanthus parviflorus (D. Don) Spreng. & Gesneriaceae \\
\hline Agapanthus umbellatus & Agapanthus africanus (L.) Hoffmanns. & $\begin{array}{l}\text { Amaryllidaceae (subfam. } \\
\text { Agapanthoideae) }\end{array}$ \\
\hline Agave americana & Agave americana L. & $\begin{array}{l}\text { Asparagaceae (subfam. } \\
\text { Agavoideae) }\end{array}$ \\
\hline Agave filamentosa & Agave filifera Salm-Dyck & $\begin{array}{l}\text { Asparagaceae (subfam. } \\
\text { Agavoideae) }\end{array}$ \\
\hline Albuca altissima & Albuca canadensis (L.) F.M. Leight. & $\begin{array}{l}\text { Asparagaceae (subfam. } \\
\text { Scilloideae) }\end{array}$ \\
\hline Albuca major & Albuca canadensis (L.) F.M. Leight. & $\begin{array}{l}\text { Asparagaceae (subfam. } \\
\text { Scilloideae) }\end{array}$ \\
\hline Alisma plantago & Alisma plantago-aquatica L. & Alismataceae \\
\hline Alliona ovata & irrisolto (PLK) & \\
\hline Aloe carinata & Gasteria carinata (Mill.) Duval & $\begin{array}{l}\text { Xanthorrhoeaceae (subfam. } \\
\text { Asphodeloideae) }\end{array}$ \\
\hline Aloe ciliaris & Aloe ciliaris Haw. & $\begin{array}{l}\text { Xanthorrhoeaceae (subfam. } \\
\text { Asphodeloideae) }\end{array}$ \\
\hline Aloe humilis & Aloe humilis Mill. & $\begin{array}{l}\text { Xanthorrhoeaceae (subfam. } \\
\text { Asphodeloideae) }\end{array}$ \\
\hline Aloe lingua latifolia & Aloe plicatilis Mill. & $\begin{array}{l}\text { Xanthorrhoeaceae (subfam. } \\
\text { Asphodeloideae) }\end{array}$ \\
\hline
\end{tabular}




\begin{tabular}{|c|c|c|}
\hline Nome secondo Balsamo Crivelli & Identità attuale del taxon & Famiglia \\
\hline Aloe macra & Aloe macra Haw. & $\begin{array}{l}\text { Xanthorrhoeaceae (subfam. } \\
\text { Asphodeloideae) }\end{array}$ \\
\hline Aloe Radula & $\begin{array}{l}\text { Haworthia attenuata (Haw.) Haw. var. radula } \\
\text { (Jacq.) M.B. Bayer }\end{array}$ & $\begin{array}{l}\text { Xanthorrhoeaceae (subfam. } \\
\text { Asphodeloideae) }\end{array}$ \\
\hline Aloe rhodocantha & Aloe glauca Mill. & $\begin{array}{l}\text { Xanthorrhoeaceae (subfam. } \\
\text { Asphodeloideae) }\end{array}$ \\
\hline Aloe umbellata & Aloe maculata All. & $\begin{array}{l}\text { Xanthorrhoeaceae (subfam. } \\
\text { Asphodeloideae) }\end{array}$ \\
\hline Aloe vulgaris & Aloe vera (L.) Burm.f. & $\begin{array}{l}\text { Xanthorrhoeaceae (subfam. } \\
\text { Asphodeloideae) }\end{array}$ \\
\hline Alonsoa grandiflora & Alonsoa meridionalis (L. f.) Kuntze & $\begin{array}{l}\text { Scrophulariaceae (subfam. } \\
\text { Scrophularioideae) }\end{array}$ \\
\hline Alstroemeria psittacina & Alstroemeria pulchella L. f. & Alstroemeriaceae \\
\hline Amaryllis Atamasco & Zephyranthes atamasco (L.) Herb. & $\begin{array}{l}\text { Amaryllidaceae (subfam. } \\
\text { Amaryllidoideae) }\end{array}$ \\
\hline Amaryllis Belladonna & Amaryllis belladonna L. & $\begin{array}{l}\text { Amaryllidaceae (subfam. } \\
\text { Amaryllidoideae) }\end{array}$ \\
\hline Amaryllis brasiliensis & Hippeastrum puniceum (Lam.) Voss & $\begin{array}{l}\text { Amaryllidaceae (subfam. } \\
\text { Amaryllidoideae) }\end{array}$ \\
\hline Amaryllis formosissima & Sprekelia formosissima (L.) Herb. & $\begin{array}{l}\text { Amaryllidaceae (subfam. } \\
\text { Amaryllidoideae) }\end{array}$ \\
\hline Amaryllis Gravini & epiteto non trovato $\left(^{*}\right)$ & \\
\hline Amaryllis haemaenthoides & Haemanthus amarylloides Jacq. & $\begin{array}{l}\text { Amaryllidaceae (subfam. } \\
\text { Amaryllidoideae) }\end{array}$ \\
\hline Amaryllis purpurea & Cyrtanthus elatus (Jacq.) Traub & $\begin{array}{l}\text { Amaryllidaceae (subfam. } \\
\text { Amaryllidoideae) }\end{array}$ \\
\hline Amaryllis Reginae & Hippeastrum reginae (L.) Herb. & $\begin{array}{l}\text { Amaryllidaceae (subfam. } \\
\text { Amaryllidoideae) }\end{array}$ \\
\hline Amaryllis rutila & Hippeastrum striatum (Lam.) H.E. Moore & $\begin{array}{l}\text { Amaryllidaceae (subfam. } \\
\text { Amaryllidoideae) }\end{array}$ \\
\hline Amaryllis sarniensis & Nerine sarniensis (L.) Herb. & $\begin{array}{l}\text { Amaryllidaceae (subfam. } \\
\text { Amaryllidoideae) }\end{array}$ \\
\hline Amaryllis tubispatha & Habranthus tubispathus (L'Hér.) Traub & $\begin{array}{l}\text { Amaryllidaceae (subfam. } \\
\text { Amaryllidoideae) }\end{array}$ \\
\hline Amaryllis undulata & Nerine undulata (L.) Herb. & $\begin{array}{l}\text { Amaryllidaceae (subfam. } \\
\text { Amaryllidoideae) }\end{array}$ \\
\hline Amaryllis vittata & Hippeastrum vittatum (L'Hér.) Herb. & $\begin{array}{l}\text { Amaryllidaceae (subfam. } \\
\text { Amaryllidoideae) }\end{array}$ \\
\hline Amyris maritima & irrisolto: 2 omonimi & \\
\hline Anagyris foetida & Anagyris foetida L. & Fabaceae \\
\hline Andropogon citratus & Cymbopogon citratus (DC.) Stapf & Poaceae \\
\hline Anona Cherimolia & Annona cherimola Mill. & Annonaceae \\
\hline Anona muricata & Annona muricata L. & Annonaceae \\
\hline Anthericum longiscapum & Bulbine asphodeloides (L.) Spreng. & $\begin{array}{l}\text { Xanthorrhoeaceae (subfam. } \\
\text { Asphodeloideae) }\end{array}$ \\
\hline Anthyllis Barba-jovis & Anthyllis barba-jovis L. & Fabaceae \\
\hline Anthyllis hermanniae & Anthyllis hermanniae L. & Fabaceae \\
\hline Anthyllis a....ium & epiteto non letto & \\
\hline Aralia capitata & Oreopanax capitatus (Jacq.) Decne. \& Planch. & Araliaceae \\
\hline
\end{tabular}




\begin{tabular}{|c|c|c|}
\hline Nome secondo Balsamo Crivelli & Identità attuale del taxon & Famiglia \\
\hline Ardisia crenulata & Ardisia crenata Sims & $\begin{array}{l}\text { Primulaceae (subfam. } \\
\text { Myrsinoideae) }\end{array}$ \\
\hline Aristolochia pistolochia & Aristolochia pistolochia L. & Aristolochiaceae \\
\hline Aristotelia macqui & Aristotelia chilensis (Molina) Stuntz & Elaeocarpaceae \\
\hline Armeria fasciculata & Armeria pungens (Link) Hoffmanns. \& Link & Plumbaginaceae \\
\hline Artemisia santonica & irrisolto: 4 omonimi & \\
\hline Arum colocasia & Colocasia esculenta (L.) Schott & Araceae \\
\hline Calla Dracontium & Monstera adansonii Schott & Araceae \\
\hline Asclepias amoena & irrisolto: 2 omonimi & \\
\hline Asclepias angustifolia & irrisolto: 4 omonimi & \\
\hline Asclepias mexicana & Asclepias fascicularis Decne. & Apocynaceae \\
\hline Astrapaea Wallichii & Dombeya wallichii (Lindl.) K. Schum. & $\begin{array}{l}\text { Malvaceae (subfam. } \\
\text { Dombeyoideae) }\end{array}$ \\
\hline Atraphaxis undulata & irrisolto: 2 omonimi & \\
\hline Aubretia deltoidea & Aubrieta deltoidea (L.) DC. & Brassicaceae \\
\hline Azalea indica & Rhododendron indicum (L.) Sweet & Ericaceae \\
\hline Baeobotrys indica & Maesa indica (Roxb.) A. DC. & $\begin{array}{l}\text { Primulaceae (subfam. } \\
\text { Maesoideae) }\end{array}$ \\
\hline Balmeda corylifolia & Grewia villosa Willd. & $\begin{array}{l}\text { Malvaceae (subfam. } \\
\text { Grewioideae) }\end{array}$ \\
\hline Banisteria laurifolia & Heteropterys laurifolia (L.) A. Juss. & Malpighiaceae \\
\hline Banksia ilicifolia & Banksia ilicifolia R. Br. & Proteaceae \\
\hline Bauhina aculeata & Bauhinia aculeata L. & Fabaceae \\
\hline Begonia anisophylla & epiteto non trovato & \\
\hline Begonia cucullata & Begonia cucullata Willd. & Begoniaceae \\
\hline Begonia digitata & Begonia digitata Raddi & Begoniaceae \\
\hline Begonia discolor & Begonia grandis Dryand. & Begoniaceae \\
\hline Betula nana & Betula nana L. & Betulaceae \\
\hline Bignonia capensis & Tecomaria capensis (Thunb.) Spach & Bignoniaceae \\
\hline Bignonia pandurata & Pandorea pandorana (Andrews) Steenis & Bignoniaceae \\
\hline Bignonia stans & Tecoma stans (L.) Kunth & Bignoniaceae \\
\hline Billardiera scandens & Billardiera scandens Sm. & Pittosporaceae \\
\hline Billbergia fasciata & Aechmea fasciata (Lindl.) Baker & Bromeliaceae \\
\hline Blephillia ciliata & Blephilia ciliata (L.) Benth. & Lamiaceae \\
\hline Bocconia frutescens & Bocconia frutescens $\mathrm{L}$. & Papaveraceae \\
\hline Bontia daphnoides & Bontia daphnoides L. & $\begin{array}{l}\text { Scrophulariaceae (subfam. } \\
\text { Myoporoideae) }\end{array}$ \\
\hline Bosea yervamora & Bosea yervamora L. & Amaranthaceae \\
\hline Bromelia Karatas & Bromelia karatas L. & Bromeliaceae \\
\hline Broussonetia tinctoria & Maclura tinctoria (L.) D. Don ex Steud. & Moraceae \\
\hline Bryonia africana & Kedrostis africana (L.) Cogn. & Cucurbitaceae \\
\hline Buddleia connata & Buddleja globosa Hope & $\begin{array}{l}\text { Scrophulariaceae (subfam. } \\
\text { Buddlejoideae) }\end{array}$ \\
\hline Buddleia saligna & Buddleja saligna Willd. & $\begin{array}{l}\text { Scrophulariaceae (subfam. } \\
\text { Buddlejoideae) }\end{array}$ \\
\hline Buddleia salicifolia & irrisolto: 3 omonimi & \\
\hline
\end{tabular}




\begin{tabular}{|c|c|c|}
\hline Nome secondo Balsamo Crivelli & Identità attuale del taxon & Famiglia \\
\hline Bumelia tenax & Sideroxylon tenax L. & Sapotaceae \\
\hline Buphthalmum pubescens & epiteto non trovato & \\
\hline Buphthalmum sericeum & Asteriscus sericeus (L. f.) DC. & Asteraceae \\
\hline Butomus umbellatus & Butomus umbellatus L. & Butomaceae \\
\hline Byrsonima laurifolia & Byrsonima crassifolia (L.) Kunth & Malpighiaceae \\
\hline Cacalia Kleinia & Kleinia neriifolia Haw. & Asteraceae \\
\hline Caladium auritum & Syngonium auritum (L.) Schott & Araceae \\
\hline Caesalpinia Nuga & Caesalpinia crista L. & Fabaceae \\
\hline Caesalpinia Sappan & Caesalpinia sappan L. & Fabaceae \\
\hline Calceolaria rugosa & Calceolaria integrifolia L. & Calceolariaceae \\
\hline Calla aethiopica & Zantedeschia aethiopica (L.) Spreng. & Araceae \\
\hline Calla palustris & Calla palustris L. & Araceae \\
\hline Callicarpa cana & irrisolto: 2 omonimi & 1 \\
\hline Caltha palustris & Caltha palustris L. & Ranunculaceae \\
\hline Camelia simplex & epiteto non trovato $(*)$ & Theaceae \\
\hline Canarina campanula & Canarina canariensis (L.) Vatke & Campanulaceae \\
\hline Canna gigantea & Canna tuerkheimii Kraenzl. & Cannaceae \\
\hline Canna iridiflora & Canna iridiflora Ruiz \& Pav. & Cannaceae \\
\hline Canna lagunensis & Canna indica L. & Cannaceae \\
\hline Capparis spinosa & Capparis spinosa L. & Capparaceae \\
\hline Carica Papaya & Carica papaya L. & Caricaceae \\
\hline Carlina salicifolia & Carlina salicifolia (L. f. ) Cav. & Asteraceae \\
\hline Carmichaelia australis & Carmichaelia australis R. Br. & Fabaceae \\
\hline Cassia ligustrina & irrisolto: 3 omonimi & \\
\hline Cassia lilacina & epiteto non trovato & \\
\hline Cassia occidentalis & Senna occidentalis (L.) Link & Fabaceae \\
\hline Cassia schinifolia & irrisolto (PLK) & \\
\hline Cassine maurocenia & irrisolto (PLK) & \\
\hline Casuarina torolosa & $\begin{array}{l}\text { Allocasuarina torulosa (Dryand. ex Aiton) L.A.S. } \\
\text { Johnson }\end{array}$ & Casuarinaceae \\
\hline Ceanothus (coeruleus) azureus & Ceanothus caeruleus Lag. & Rhamnaceae \\
\hline Ceratonia siliqua & Ceratonia siliqua L. & Fabaceae \\
\hline Cereus ....senii & epiteto non letto & \\
\hline Cereus mo..... & epiteto non letto & \\
\hline Cereus Napoleonis & Hylocereus trigonus (Haw.) Saff. & Cactaceae \\
\hline Cereus pentagonus & irrisolto: 2 omonimi & \\
\hline Cereus serpentinus & Disocactus flagelliformis (L.) Barthlott. & Cactaceae \\
\hline Cereus speciosissimus & Cereus speciosissimus (Desf.) DC. & Cactaceae \\
\hline Cereus tetragonus & Acanthocereus tetragonus (L.) Hummelinck & Cactaceae \\
\hline Chamaerops humilis & Chamaerops humilis L. & Arecaceae \\
\hline Chelone obliqua & Chelone obliqua L. & Plantaginaceae \\
\hline Chrysocoma Coma aurea & Chrysocoma coma-aurea L. & Asteraceae \\
\hline Chrysophyllum Cainito & Chrysophyllum cainito L. & Sapotaceae \\
\hline Chrysophyllum cinereum & Synsepalum brevipes (Baker) T.D. Penn. & Sapotaceae \\
\hline
\end{tabular}




\begin{tabular}{|c|c|c|}
\hline Nome secondo Balsamo Crivelli & Identità attuale del taxon & Famiglia \\
\hline Chrysophyllum subserratum & epiteto non trovato & \\
\hline Cicuta virosa & Cicuta virosa $L$. & Apiaceae \\
\hline Cineraria maritima & Jacobaea maritima (L) Pelser \& Meijden & Asteraceae \\
\hline Cineraria platanifolia & Roldana petasitis (Sims) H. Rob. \& Brettell & Asteraceae \\
\hline Cissus antarctica & Cissus antarctica Vent. & Vitaceae \\
\hline Cistus crispus & Cistus crispus L. & Cistaceae \\
\hline Cistus heterophyllus & Cistus heterophyllus Desf. & Cistaceae \\
\hline Cistus ladaniferus & Cistus ladanifer L. & Cistaceae \\
\hline Citrus aurantium & Citrus aurantium L. & Rutaceae \\
\hline Clerodendron ligustrinum & Clerodendrum ligustrinum (Jacq.) R. Br. & Lamiaceae \\
\hline Clethra arborea & Clethra arborea Aiton & Clethraceae \\
\hline Clianthus puniceus & Clianthus puniceus (G. Don) Lindl. & Fabaceae \\
\hline Clusia rosea & Clusia rosea Jacq. & Clusiaceae \\
\hline Cluytia alaternoides & Clutia alaternoides L. & Peraceae \\
\hline Cneorum tricoccum & Cneorum tricoccon $\mathrm{L}$. & Rutaceae \\
\hline Cobaea scandens & Cobaea scandens Cav. & Polemoniaceae \\
\hline Coccoloba excoriata & Coccoloba tenuifolia L. & Polygonaceae \\
\hline Coccoloba fagifolia & Coccoloba coronata Jacq. & Polygonaceae \\
\hline Coffea arabica & Coffea arabica L. & Rubiaceae \\
\hline Colletia spinosa & Colletia spinosissima J.F. Gmel. & Rhamnaceae \\
\hline Comarum palustre & Fragaria palustris (L.) Crantz & Rosaceae \\
\hline Commelina coelestis & Commelina coelestis Willd. & Commelinaceae \\
\hline Convolvulus sabatius & Convolvulus sabatius Viv. & Convolvulaceae \\
\hline Cookia punctata & irrisolto: 3 omonimi & \\
\hline Cordia m....ira & epiteto non letto & \\
\hline Cordia patagonula & Cordia americana (L.) Gottschling \& J.S. Mill. & Boraginaceae \\
\hline Cordia obliqua & irrisolto: 3 omonimi & \\
\hline Cordyline congesta? & Cordyline congesta (Sweet) Steud. & $\begin{array}{l}\text { Asparagaceae (subfam. } \\
\text { Lomandroideae) }\end{array}$ \\
\hline Coronilla valentina & Coronilla valentina $L$. & Fabaceae \\
\hline Corraea alba & Correa alba Andrews & Rutaceae \\
\hline Costus speciosus & Cheilocostus speciosus (J. König) C. Specht & Costaceae \\
\hline Cotiledon coccineum & Echeveria coccinea (Cav.) DC. & Crassulaceae \\
\hline Crassula arborescens & Crassula arborescens (Mill.) Willd. & Crassulaceae \\
\hline Crassula lactea & Crassula lactea Aiton & Crassulaceae \\
\hline Crassula pellucida & Crassula pellucida L. & Crassulaceae \\
\hline Crassula portulaca & Crassula ovata (Mill.) Druce & Crassulaceae \\
\hline Crinum americanum & Crinum americanum $\mathrm{L}$. & $\begin{array}{l}\text { Amaryllidaceae (subfam. } \\
\text { Amaryllidoideae) }\end{array}$ \\
\hline Crinum amoenum & Crinum amoenum Roxb. ex Ker Gawl. & $\begin{array}{l}\text { Amaryllidaceae (subfam. } \\
\text { Amaryllidoideae) }\end{array}$ \\
\hline Crinum latifolium & Crinum latifolium L. & $\begin{array}{l}\text { Amaryllidaceae (subfam. } \\
\text { Amaryllidoideae) }\end{array}$ \\
\hline Curculigo sumatrana & $\begin{array}{l}\text { Molineria latifolia (Dryand. ex W.T. Aiton) Herb. } \\
\text { ex Kurz }\end{array}$ & Hypoxidaceae \\
\hline
\end{tabular}




\begin{tabular}{|c|c|c|}
\hline Nome secondo Balsamo Crivelli & Identità attuale del taxon & Famiglia \\
\hline Curcuma lunga & Curcuma longa L. & Zingiberaceae \\
\hline Cussonia thysiflora & Cussonia thyrsiflora Thunb. & Araliaceae \\
\hline Cymbidium ensifolium & Cymbidium ensifolium (L.) Sw. & Orchidaceae \\
\hline Dais cotinifolia & Dais cotinifolia $\mathbf{L}$. & Thymelaeaceae \\
\hline Datura arborea & Brugmansia arborea (L.) Steud. & Solanaceae \\
\hline Datura sanguinea & Brugmansia sanguinea (Ruiz \& Pav.) D. Don & Solanaceae \\
\hline Daubentonia tripetiana & irrisolto (PLK) & \\
\hline Deeringia celosioides & Deeringia amaranthoides (Lam.) Merr. & Amaranthaceae \\
\hline Desmanthus virgatus & Desmanthus virgatus (L.) Willd. & Fabaceae \\
\hline Dianella coerulea & Dianella caerulea Sims & $\begin{array}{l}\text { Xanthorrhoeaceae (subfam. } \\
\text { Hemerocallidoideae) }\end{array}$ \\
\hline Diosma capitata & Audouinia capitata (L.) Brongn. & Bruniaceae \\
\hline Diosma cordata & Agathosma imbricata (L.) Willd. & Rutaceae \\
\hline Diosma fragrans & Adenandra fragrans (Sims) Schult. & Rutaceae \\
\hline Dodecatheon meadia & Primula meadia (L.) A.R. Mast \& Reveal & Primulaceae \\
\hline Dombeya ferruginea & Dombeya ferruginea Cav. & $\begin{array}{l}\text { Malvaceae (subfam. } \\
\text { Dombeyoideae) }\end{array}$ \\
\hline Dorstenia contrayerva & Dorstenia contrajerva L. & Moraceae \\
\hline Dracaena brasiliensis & Cordyline fruticosa (L.) A. Chev. & $\begin{array}{l}\text { Asparagaceae (subfam. } \\
\text { Lomandroideae) }\end{array}$ \\
\hline Dracaena draco & Dracaena draco $\mathrm{L}$. & $\begin{array}{l}\text { Asparagaceae (subfam. } \\
\text { Nolinoideae) }\end{array}$ \\
\hline Dracaena fragrans & Dracaena fragrans (L.) Ker Gawl. & $\begin{array}{l}\text { Asparagaceae (subfam. } \\
\text { Nolinoideae) }\end{array}$ \\
\hline Dracaena reflexa & Dracaena reflexa Lam. & $\begin{array}{l}\text { Asparagaceae (subfam. } \\
\text { Nolinoideae) }\end{array}$ \\
\hline Drymia undulata & Ledebouria undulata (Jacq.) Jessop & $\begin{array}{l}\text { Asparagaceae (subfam. } \\
\text { Scilloideae) }\end{array}$ \\
\hline Duranta microphylla & Duranta erecta L. & Verbenaceae \\
\hline Echinocactus ottonis & irrisolto (PLK) & \\
\hline Echium candicans & Echium candicans L. f. & Boraginaceae \\
\hline Ehretia tinifolia & Ehretia tinifolia L. & Boraginaceae \\
\hline Elaeagnus argentea & irrisolto: 2 omonimi & \\
\hline Embothrium silaifolium & Lomatia silaifolia $(\mathrm{Sm}.) \mathrm{R} . \mathrm{Br}$. & Proteaceae \\
\hline Entelea arborescens & Entelea arborescens R. Br. & $\begin{array}{l}\text { Malvaceae (subfam. } \\
\text { Grewioideae) }\end{array}$ \\
\hline Epilobium hirsutum & Epilobium hirsutum L. & Onagraceae \\
\hline Epidendron aloifolium & irrisolto: 2 omonimi & \\
\hline Erica scoparia & Erica scoparia L. & Ericaceae \\
\hline Erinus alpinus & Erinus alpinus L. & Plantaginaceae \\
\hline Erythrina abyssinica & Erythrina abyssinica DC. & Fabaceae \\
\hline Erythrina corralodendron & Erythrina corallodendron L. & Fabaceae \\
\hline Erythrina cristagalli & Erythrina crista-galli L. & Fabaceae \\
\hline Erythrina laurifolia & Erythrina crista-galli L. & Fabaceae \\
\hline Erythrina velutina & Erythrina velutina Willd. & Fabaceae \\
\hline Escalonia rubra & Escallonia rubra (Ruiz \& Pav.) Pers. & Escalloniaceae \\
\hline
\end{tabular}




\begin{tabular}{|c|c|c|}
\hline Nome secondo Balsamo Crivelli & Identità attuale del taxon & Famiglia \\
\hline Eucomis regia & Eucomis regia (L.) Aiton & $\begin{array}{l}\text { Asparagaceae (subfam. } \\
\text { Scilloideae) }\end{array}$ \\
\hline Eugenia nervosa & Eugenia nervosa Lour. & Myrtaceae \\
\hline Eugenia uniflora & Eugenia uniflora L. & Myrtaceae \\
\hline Euphorbia decagona & epiteto non trovato $(*)$ & \\
\hline Euphorbia dendroides & Euphorbia dendroides L. & Euphorbiaceae \\
\hline Euphorbia nerifolia & Euphorbia neriifolia L. & Euphorbiaceae \\
\hline Euphorbia orientalis & Euphorbia orientalis L. & Euphorbiaceae \\
\hline Euphorbia speciosa & Euphorbia speciosa L.C. Leach & Euphorbiaceae \\
\hline Euphoria Litchii & irrisolto (PLK) & \\
\hline Fabricia alba & Spiloxene alba (Thunb.) Fourc. & Hypoxidaceae \\
\hline Falkia repens & Falkia repens L. f. & Convolvulaceae \\
\hline Ferraria pavonia & Tigridia pavonia (L. f.) DC. & Iridaceae \\
\hline Ferreola undulata & Diospyros undulata Wall. ex G. Don & Ebenaceae \\
\hline Freylinia cestroides & Freylinia lanceolata (L.) G. Don & $\begin{array}{l}\text { Scrophulariaceae (subfam. } \\
\text { Scrophularioideae) }\end{array}$ \\
\hline Ficus aquatica & Ficus heterophylla L. f. & Moraceae \\
\hline Ficus arbutifolia & irrisolto: 2 omonimi & \\
\hline Ficus capensis & Ficus sur Forssk. & Moraceae \\
\hline Ficus carenata & Ficus carinata C.C. Berg & Moraceae \\
\hline Ficus elastica & Ficus elastica Roxb. ex Hornem. & Moraceae \\
\hline Ficus exasperata & Ficus exasperata Vahl & Moraceae \\
\hline Ficus glauca & Ficus glauca Miq. & Moraceae \\
\hline Ficus laurifolia & Ficus maxima Mill. & Moraceae \\
\hline Ficus lutescens & Ficus deltoidea Jack & Moraceae \\
\hline Ficus pendula & Ficus benjamina L. & Moraceae \\
\hline Ficus popolifolia & Ficus populifolia Vahl & Moraceae \\
\hline Ficus pumila & Ficus pumila L. & Moraceae \\
\hline Ficus racemosa & Ficus racemosa L. & Moraceae \\
\hline Ficus scaber & Ficus scabra G. Forst. & Moraceae \\
\hline Ficus stipitata & Ficus densistipulata De Wild & Moraceae \\
\hline Ficus terebrata & Ficus reflexa Thunb. & Moraceae \\
\hline Ficus venosa & irrisolto: 2 omonimi & \\
\hline Fuchsia compacta & epiteto non trovato $(*)$ & \\
\hline Fuchsia cordifolia & Fuchsia splendens Zucc. & Onagraceae \\
\hline Fuchsia corymbiflora & Fuchsia corymbiflora Ruiz \& Pav. & Onagraceae \\
\hline Fuchsia mexicana & epiteto non trovato & \\
\hline Fuchsia ovalis & Fuchsia ovalis Ruiz \& Pav. & Onagraceae \\
\hline Fuchsia pedunculata & epiteto non trovato & \\
\hline Fuchsia Standishii & irrisolto (PLK) & \\
\hline Fuchsia Woodii & epiteto non trovato & \\
\hline Gailardia picta & Gaillardia pulchella Foug. & Asteraceae \\
\hline Gardenia Thunbergia & Gardenia thunbergia Thunb. & Rubiaceae \\
\hline Garuga pinnata & Garuga pinnata Roxb. & Burseraceae \\
\hline
\end{tabular}




\begin{tabular}{|c|c|c|}
\hline Nome secondo Balsamo Crivelli & Identità attuale del taxon & Famiglia \\
\hline Gendarussa furcata & irrisolto (PLK) & \\
\hline Gesneria bulbosa & irrisolto (PLK) & \\
\hline Gladiolus psittacinus & Gladiolus dalenii Van Geel & Iridaceae \\
\hline Globba nutans & Alpinia nutans (L.) Roscoe & Zingiberaceae \\
\hline Globularia integrifolia & epiteto non trovato & \\
\hline Gloxinia speciosa & Sinningia speciosa Hiern & Gesneriaceae \\
\hline Gloxinia (s)po.... & epiteto non letto & \\
\hline Gloxinia Zebrina & epiteto non trovato $(*)$ & \\
\hline Goldfussia Sabini & epiteto non trovato $(*)$ & \\
\hline Goodia lotifolia & Goodia lotifolia Salisb. & Fabaceae \\
\hline Grevillea rosmarinifolia & Grevillea rosmarinifolia A. Cunn. & Proteaceae \\
\hline Grewia orientalis & Grewia orientalis L. & $\begin{array}{l}\text { Malvaceae (subfam. } \\
\text { Grewioideae) }\end{array}$ \\
\hline Guilandina Bonduc & Guilandina bonduc L. & Fabaceae \\
\hline Gyrocarpus americanus & Gyrocarpus americanus Jacq. & Hernandiaceae \\
\hline Haemanthus puniceus & Scadoxus puniceus (L.) Friis \& Nordal & $\begin{array}{l}\text { Amaryllidaceae (subfam. } \\
\text { Amaryllidoideae) }\end{array}$ \\
\hline Halleria lucida & Halleria lucida L. & Stilbaceae \\
\hline Haloragis cercodia & irrisolto (PLK) & \\
\hline Hamelia patens & Hamelia patens Jacq. & Rubiaceae \\
\hline Hedychium coronarium & Hedychium coronarium J. König & Zingiberaceae \\
\hline Hedychium gardnerianum & $\begin{array}{l}\text { Hedychium gardnerianum Sheppard ex Ker } \\
\text { Gawl. }\end{array}$ & Zingiberaceae \\
\hline Heimia myrtifolia & Heimia myrtifolia Cham. \& Schltdl. & Lythraceae \\
\hline Helicteres jamaicensis & Helicteres jamaicensis Jacq. & $\begin{array}{l}\text { Malvaceae (subfam. } \\
\text { Helicteroideae) }\end{array}$ \\
\hline Heliotropium peruvianum & Heliotropium arborescens L. & Boraginaceae \\
\hline Hermannia distica & irrisolto (PLK) & \\
\hline Hibbertia volubilis & irrisolto (PLK) & \\
\hline Hibiscus heterophillus & Hibiscus heterophyllus Vent. & $\begin{array}{l}\text { Malvaceae (subfam. } \\
\text { Malvoideae) }\end{array}$ \\
\hline Hibiscus liliiflorus & irrisolto: 2 omonimi & \\
\hline Hibiscus Manihot & Abelmoschus manihot (L.) Medik. & $\begin{array}{l}\text { Malvaceae (subfam. } \\
\text { Malvoideae) }\end{array}$ \\
\hline Hibiscus mutabilis & Hibiscus mutabilis L. & $\begin{array}{l}\text { Malvaceae (subfam. } \\
\text { Malvoideae) }\end{array}$ \\
\hline Hibiscus Rosasinensis & Hibiscus rosa-sinensis L. & $\begin{array}{l}\text { Malvaceae (subfam. } \\
\text { Malvoideae) }\end{array}$ \\
\hline Hibiscus flavorubra & Hibiscus rosa-sinensis L. cv. & $\begin{array}{l}\text { Malvaceae (subfam. } \\
\text { Malvoideae) }\end{array}$ \\
\hline Hoja carnosa & Hoya carnosa (L. f.) R. Br. & Apocynaceae \\
\hline Hippophaë canadensis & Shepherdia canadensis (L.) Nutt. & Elaeagnaceae \\
\hline Hydrocotile bonariensis & Hydrocotyle bonariensis Lam. & Araliaceae \\
\hline Hydrocotile vulgaris & Hydrocotyle vulgaris L. & Araliaceae \\
\hline Hyperanthera moringa & Moringa oleifera Lam. & Moringaceae \\
\hline Hypericum kalmianum & Hypericum kalmianum L. & Hypericaceae \\
\hline Ilex caroliniana & Ilex cassine $\mathrm{L}$. & Aquifoliaceae \\
\hline
\end{tabular}




\begin{tabular}{|c|c|c|}
\hline Nome secondo Balsamo Crivelli & Identità attuale del taxon & Famiglia \\
\hline Ilex cassine & Ilex cassine $\mathrm{L}$. & Aquifoliaceae \\
\hline Illicium anisatum & Illicium anisatum $\mathrm{L}$. & Schisandraceae \\
\hline Ixia finestrata & Tritonia crocata (L.) Ker Gawl. & Iridaceae \\
\hline Jasminum azoricum & Jasminum azoricum L. & Oleaceae \\
\hline Jasminum heterophyllum & irrisolto: 2 omonimi & \\
\hline Jatropha napaelifolia & Cnidoscolus aconitifolius (Mill.) I.M. Johnst. & Euphorbiaceae \\
\hline Justicia bicolor & irrisolto (PLK) & \\
\hline Justicia bracteata & irrisolto: 3 omonimi & \\
\hline Justicia card.... & epiteto non letto & \\
\hline Justicia flavescens & epiteto non trovato & \\
\hline Justicia formosa & irrisolto: 2 omonimi & \\
\hline Justicia Gendarussa & Justicia gendarussa Burm. f. & Acanthaceae \\
\hline Justicia nasuta & Rhinacanthus nasutus (L.) Kurz & Acanthaceae \\
\hline Kaempferia rotunda & Kaempferia rotunda L. & Zingiberaceae \\
\hline Kiggellaria africana & Kiggelaria africana $\mathrm{L}$. & Achariaceae \\
\hline Lachenalia lanceaefolia & Ledebouria revoluta (L. f.) Jessop & Asparagaceae (Scilloideae) \\
\hline Lantana alba & irrisolto: 2 omonimi & \\
\hline Laurus angustifolia & irrisolto (PLK) & \\
\hline Laurus borbonica & Persea borbonia (L.) Spreng. & Lauraceae \\
\hline Laurus foetens & Ocotea foetens (Aiton) Baill. (PLK: irrisolto) & Lauraceae \\
\hline Laurus indica & Persea indica (L.) Spreng. & Lauraceae \\
\hline Laurus nobilis & Laurus nobilis L. & Lauraceae \\
\hline Laurus tomentosa & Cinnamomum tomentosum D. Don & Lauraceae \\
\hline Lavatera olbia & Malva olbia (L.) Alef. & $\begin{array}{l}\text { Malvaceae (subfam. } \\
\text { Malvoideae) }\end{array}$ \\
\hline Leersia oryzoides & Leersia oryzoides (L.) Sw. & Poaceae \\
\hline Lepismium paradoxum & $\begin{array}{l}\text { Rhipsalis paradoxa (Salm-Dyck ex Pfeiff.) Salm- } \\
\text { Dyck }\end{array}$ & Cactaceae \\
\hline Litorella lacustris & Plantago uniflora L. & Plantaginaceae \\
\hline Lomandra angustifolia & epiteto non trovato & \\
\hline Lomatophyllum borbonicum & Aloë purpurea Lam. & $\begin{array}{l}\text { Xanthorrhoeaceae (subfam. } \\
\text { Asphodeloideae) }\end{array}$ \\
\hline Lophospermum scandens & Lophospermum scandens D. Don & Plantaginaceae \\
\hline Loureiria cuneifolia & Jatropha dioica Sessé & Euphorbiaceae \\
\hline Lycium boerhaviaefolium & irrisolto (PLK) & \\
\hline Magnolia fuscata & Magnolia figo (Lour.) DC. & Magnoliaceae \\
\hline Magnolia pumila & Magnolia liliifera (L.) Baill. & Magnoliaceae \\
\hline Malpighia aquifolium & Malpighia aquifolia L. & Malpighiaceae \\
\hline Malpighia coccifera & Malpighia coccigera L. & Malpighiaceae \\
\hline Malpighia laurifolia & Byrsonima crassifolia (L.) Kunth & Malpighiaceae \\
\hline Malva miniata & Sphaeralcea miniata (Cav.) Spach & $\begin{array}{l}\text { Malvaceae (subfam. } \\
\text { Malvoideae) }\end{array}$ \\
\hline Malvaviscus arboreus & Malvaviscus arboreus Cav. & $\begin{array}{l}\text { Malvaceae (subfam. } \\
\text { Malvoideae) }\end{array}$ \\
\hline Margyricarpos setosus & Margyricarpus pinnatus (Lam.) Kuntze & Rosaceae \\
\hline
\end{tabular}




\begin{tabular}{|c|c|c|}
\hline Nome secondo Balsamo Crivelli & Identità attuale del taxon & Famiglia \\
\hline Marsilea quadrifolia & Marsilea quadrifolia L. & Marsileaceae \\
\hline Medeola asparagoides & Asparagus asparagoides (L.) Druce & $\begin{array}{l}\text { Asparagaceae (subfam. } \\
\text { Asparagoideae) }\end{array}$ \\
\hline Medicago arborea & Medicago arborea L. & Fabaceae \\
\hline Melaleuca armillaris & Melaleuca armillaris (Sol. ex Gaertn.) Sm. & Myrtaceae \\
\hline Melaleuca hypericifolia & Melaleuca hypericifolia Sm. & Myrtaceae \\
\hline Melaleuca splendens & Metrosideros fulgens Sol. ex Gaertn. & Myrtaceae \\
\hline Melaleuca trinervia & Leptospermum trinervium (Sm.) Joy Thomps. & Myrtaceae \\
\hline Melastoma albicans & Miconia albicans (Sw.) Steud. & Melastomataceae \\
\hline Melastoma grandiflora & Rhynchanthera grandiflora (Aubl.) DC. & Melastomataceae \\
\hline Melastoma holosericea & Miconia holosericea (L.) DC. & Melastomataceae \\
\hline Melianthus major & Melianthus major L. & Melianthaceae \\
\hline Menispermum laurifolium & Cocculus laurifolius DC. & Menispermaceae \\
\hline Menyanthes trifoliata & Menyanthes trifoliata L. & Menyanthaceae \\
\hline Mesembrianthemum acinaciforme & Carpobrotus acinaciformis L. Bolus & Aizoaceae \\
\hline Mesembrianthemum deltoides & Oscularia deltoides (L.) Schwantes & Aizoaceae \\
\hline Mesembrianthemum falcatum & Lampranthus falcatus (L.) N.E. Br. & \\
\hline Mesembrianthemum glandulosa & epiteto non trovato & \\
\hline Mesembrianthemum glauca & Lampranthus glaucus (L.) N.E. Br. & Aizoaceae \\
\hline Mesembrianthemum hirtellum & irrisolto: 3 omonimi & \\
\hline Mesembrianthemum maximum & irrisolto (PLK) & \\
\hline Mesembrianthemum noctiflorum & Aridaria noctiflora (L.) N.E. Br. & Aizoaceae \\
\hline Mesembrianthemum praepingue & irrisolto (PLK) & \\
\hline Mesembrianthemum umbellatum & irrisolto: 2 omonimi & \\
\hline Metrosideros angustifolius & Metrosideros angustifolia (L.) Sm. & Myrtaceae \\
\hline Mimosa Nova & epiteto non trovato $(*)$ & \\
\hline Mimosa sensitiva & Mimosa sensitiva L. & Fabaceae \\
\hline Mimosa pudica & Mimosa pudica L. & Fabaceae \\
\hline Mimulus cardinalis & Mimulus cardinalis Douglas ex Benth. & Phrymaceae \\
\hline Monetia barlerioides & Azima tetracantha Lam. & Salvadoraceae \\
\hline Musa discolor & Musa x paradisiaca L. pro sp. & Musaceae \\
\hline Myrthus baetica & Myrtus communis L. subsp. communis & Myrtaceae \\
\hline Myrthus pimenta & Pimenta dioica (L.) Merr. & Myrtaceae \\
\hline Myrthus romana & Myrtus communis L. subsp. communis & Myrtaceae \\
\hline Myrthus tarentina & $\begin{array}{l}\text { Myrtus communis L. subsp. tarentina (L.) } \\
\text { Nyman }\end{array}$ & Myrtaceae \\
\hline Nerium Oleander album & Nerium oleander L. & Apocynaceae \\
\hline Nerium splendens & Nerium oleander L. & Apocynaceae \\
\hline Nicotiana glauca & Nicotiana glauca Graham & Solanaceae \\
\hline Nocca rigida & Lagascea rigida (Cav.) Stuessy & Asteraceae \\
\hline Nymphaea alba & Nymphaea alba L. & Nymphaeaceae \\
\hline Ocymum carnosum & $\begin{array}{l}\text { Ocimum carnosum (Spreng.) Link \& Otto ex } \\
\text { Benth. }\end{array}$ & Lamiaceae \\
\hline Olea europaea & Olea europaea L. & Oleaceae \\
\hline Olea fragrans & Osmanthus fragrans (Thunb.) Lour. & Oleaceae \\
\hline
\end{tabular}




\begin{tabular}{|c|c|c|}
\hline Nome secondo Balsamo Crivelli & Identità attuale del taxon & Famiglia \\
\hline Origanum Onites & Origanum onites L. & Lamiaceae \\
\hline Opuntia aurantiaca & Opuntia aurantiaca Lindl. & Cactaceae \\
\hline Opuntia brasiliensis & Brasiliopuntia brasiliensis (Willd.) A. Berger & Cactaceae \\
\hline Opuntia catocantha & irrisolto (PLK) & \\
\hline Opuntia curassavica & Opuntia curassavica (L.) Mill. & Cactaceae \\
\hline Opuntia cylindrica & Cylindropuntia cylindrica (Lam.) F.M. Knuth & Cactaceae \\
\hline Opuntia dejecta & Nopalea dejecta (Salm-Dyck) Salm-Dyck & Cactaceae \\
\hline Opuntia glaucescens & Opuntia stenopetala Engelm. & Cactaceae \\
\hline Opuntia piccolomini & irrisolto (PLK) & \\
\hline Opuntia tomentosa & Opuntia tomentosa Salm-Dyck & Cactaceae \\
\hline Opuntia undulata & Opuntia undulata Griffiths & Cactaceae \\
\hline Ornithogalum arabicum & Ornithogalum arabicum L. & $\begin{array}{l}\text { Asparagaceae (subfam. } \\
\text { Scilloideae) }\end{array}$ \\
\hline Ornithogalum caudatum & $\begin{array}{l}\text { Albuca bracteata (Thunb.) J.C. Manning \& } \\
\text { Goldbl. }\end{array}$ & $\begin{array}{l}\text { Asparagaceae (subfam. } \\
\text { Scilloideae) }\end{array}$ \\
\hline Orontium japonicum & Rohdea japonica (Thunb.) Roth & $\begin{array}{l}\text { Asparagaceae (subfam. } \\
\text { Nolinoideae) }\end{array}$ \\
\hline Oxalis asinina & Oxalis fabifolia Jacq. & Oxalidaceae \\
\hline Oxalis Deppii & Oxalis tetraphylla Cav. & Oxalidaceae \\
\hline Paederia foetida & Paederia foetida L. & Rubiaceae \\
\hline Panax aculeata & Eleutherococcus trifoliatus (L.) S.Y. Hu & Araliaceae \\
\hline Passerina hirta & Thymelaea hirsuta (L.) Endl. & Thymelaeaceae \\
\hline Passiflora alata & Passiflora alata Curtis & Passifloraceae \\
\hline Passiflora alba & Passiflora subpeltata Ortega & Passifloraceae \\
\hline Passiflora coerulea & Passiflora caerulea L. & Passifloraceae \\
\hline Passiflora edulis & Passiflora edulis Sims & Passifloraceae \\
\hline Passiflora filamentosa & Passiflora filamentosa Cav. & Passifloraceae \\
\hline Passiflora princeps & Passiflora racemosa Brot. & Passifloraceae \\
\hline Passiflora pubescens & Passiflora capsularis L. & Passifloraceae \\
\hline Passiflora trilobata & Passiflora triloba Ruiz \& Pav. ex DC. & Passifloraceae \\
\hline Paulinia carthagenensis & irrisolto: 4 omonimi & \\
\hline Pelargonium amplexicaulis & epiteto non trovato & \\
\hline Pelargonium cordifolium & Pelargonium cordifolium Curtis & Geraniaceae \\
\hline Pelargonium coriandrifolium & irrisolto (PLK) & \\
\hline Pelargonium monstrum & irrisolto (PLK) & \\
\hline Pelargonium monstrosum & irrisolto (PLK) & \\
\hline Pelargonium papilionaceum & irrisolto (PLK) & \\
\hline Pelargonium peltatum & Pelargonium peltatum (L.) L’Hér. & Geraniaceae \\
\hline Pelargonium radula & Pelargonium radula (Cav.) L’Hér. & Geraniaceae \\
\hline Pelargonium sanguineum & irrisolto (PLK) & \\
\hline Pelargonium tomentosum & irrisolto: 2 omonimi & \\
\hline Pelargonium vitifolium & Pelargonium vitifolium (L.) L’Hér. & Geraniaceae \\
\hline Pentstemon perfoliatum & Penstemon perfoliatus Brongn. & Plantaginaceae \\
\hline Pereskia aculeata & Pereskia aculeata Mill. & Cactaceae \\
\hline Pereskia bleo & Pereskia bleo (Kunth) DC. & Cactaceae \\
\hline
\end{tabular}




\begin{tabular}{|c|c|c|}
\hline Nome secondo Balsamo Crivelli & Identità attuale del taxon & Famiglia \\
\hline Pereskia Iasminiflora & epiteto non trovato $(*)$ & \\
\hline Phaseolus Caracalla & Vigna caracalla (L.) Verdc. & Fabaceae \\
\hline Phlomis ferruginea & Phlomis purpurea L. & Lamiaceae \\
\hline Phoenix dactylifera & Phoenix dactylifera L. & Arecaceae \\
\hline Phormium tenax & Phormium tenax J.R. Forst. \& G. Forst. & $\begin{array}{l}\text { Xanthorrhoeaceae (subfam. } \\
\text { Hemerocallidoideae) }\end{array}$ \\
\hline Pittosporum Tobira & Pittosporum tobira (Thunb.) W.T. Aiton & Pittosporaceae \\
\hline Pittosporum undulatum & Pittosporum undulatum Vent. & Pittosporaceae \\
\hline Plectranthus fruticosa & Plectranthus fruticosus L’Hér. & Lamiaceae \\
\hline Plumbago coerulea & Plumbago caerulea Kunth & Plumbaginaceae \\
\hline Plumbago rosea & Plumbago indica L. & Plumbaginaceae \\
\hline Plumbago Zeylanica & Plumbago zeylanica L. & Plumbaginaceae \\
\hline Plumieria alba & Plumeria alba L. & Apocynaceae \\
\hline Pogonia glabra & irrisolto (PLK) & 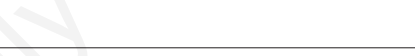 \\
\hline Polianthes tuberosa & Agave polianthes (L.) Thiede \& Eggli & $\begin{array}{l}\text { Asparagaceae (subfam. } \\
\text { Agavoideae) }\end{array}$ \\
\hline Pomaderris apetala & Pomaderris apetala (Labill.) Schult. & Rhamnaceae \\
\hline Pontederia cordata & Pontederia cordata L. & Pontederiaceae \\
\hline Porliera higrometrica & irrisolto (PLK) & \\
\hline Potamogeton natans & Potamogeton natans L. & Potamogetonaceae \\
\hline Poterium caudatum & Poterium caudatum Aiton & Rosaceae \\
\hline Pothos lanceolatus & Anthurium acaule (Jacq.) Schott & Araceae \\
\hline Psidium montanum & Psidium montanum Sw. & Myrtaceae \\
\hline Psidium pyriferum & Psidium guajava L. & Myrtaceae \\
\hline Psoralea palaestina & Bituminaria bituminosa (L.) C.H. Stirt. & Fabaceae \\
\hline Pterospermum acerifolium & Pterospermum acerifolium (L.) Willd. & $\begin{array}{l}\text { Malvaceae (subfam. } \\
\text { Dombeyoideae) }\end{array}$ \\
\hline Punica nana & Punica granatum L. 'Nana' & Lythraceae \\
\hline Quercus gramuntia & Quercus ilex L. & Fagaceae \\
\hline Quisqualis pubescens & Combretum indicum (L.) DeFilipps & Combretaceae \\
\hline Rhamnus Clusii & Rhamnus alaternus L. & Rhamnaceae \\
\hline Rhamnus glandulosa & irrisolto (PLK) & \\
\hline Rhamnus lanceolata & irrisolto (PLK) & \\
\hline Rhapis flabelliformis & Rhapis excelsa (Thunb.) Henry & Arecaceae \\
\hline Rhus lucida & Rhus lucida L. & Anacardiaceae \\
\hline Rhus semialata & Rhus chinensis Mill. & Anacardiaceae \\
\hline Rhus suaveolens & irrisolto (PLK) & \\
\hline Rhus thezera & irrisolto (PLK) & \\
\hline Rhus trifoliata & irrisolto (PLK) & \\
\hline Rhus viminalis & Rhus pendulina Jacq. & Anacardiaceae \\
\hline Rivinia brasiliensis & Rivina humilis L. & Phytolaccaceae \\
\hline Rondeletia americana & Rondeletia americana L. & Rubiaceae \\
\hline Rosmarinus officinalis & Rosmarinus officinalis L. & Lamiaceae \\
\hline Royena ambigua & irrisolto: 2 omonimi & \\
\hline Royena ....ipata & epiteto non letto & \\
\hline
\end{tabular}




\begin{tabular}{|c|c|c|}
\hline Nome secondo Balsamo Crivelli & Identità attuale del taxon & Famiglia \\
\hline Royena ....ida & epiteto non letto & \\
\hline Royena poliandra & Euclea polyandra (L. f.) E. Mey. ex Hiern & Ebenaceae \\
\hline Ruellia formosa & Ruellia elegans Poir. & Acanthaceae \\
\hline Ruellia varians & irrisolto (PLK) & \\
\hline Sabal minor & Sabal minor (Jacq.) Pers. & Arecaceae \\
\hline Saccarum off & Saccharum officinarum $\mathrm{L}$. & Poaceae \\
\hline Saggittaria saggittaefolia & Sagittaria sagittifolia L. & Alismataceae \\
\hline Sa... praticola & Salix praticola Hand.-Mazz. ex Enander & Salicaceae \\
\hline Salvia ceratophylla & Salvia ceratophylla L. & Lamiaceae \\
\hline Salvia caucasica & Salvia virgata Jacq. & Lamiaceae \\
\hline Salvia patens & Salvia patens Cav. & Lamiaceae \\
\hline Sapindus saponaria & Sapindus saponaria L. & Sapindaceae \\
\hline Satureja Thymbra & Satureja thymbra L. & Lamiaceae \\
\hline Schinus molle & Schinus molle L. & Anacardiaceae \\
\hline Sestia speciosa (?) & binomio non trovato & 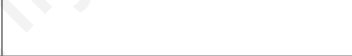 \\
\hline Scilla peruviana & Oncostema peruvianum (L.) Speta & $\begin{array}{l}\text { Asparagaceae (subfam. } \\
\text { Scilloideae) }\end{array}$ \\
\hline Scirpus lacustris & Schoenoplectus lacustris (L.) Palla & Cyperaceae \\
\hline Sempervivum arboreum & Aeonium arboreum (L.) Webb \& Berthel. & Crassulaceae \\
\hline Sempervivum tortuosum & Aichryson tortuosum (Aiton) Webb \& Berthel. & Crassulaceae \\
\hline Senecio purpureus & Senecio purpureus L. & Asteraceae \\
\hline Sida hastata & Anoda cristata (L.) Schltdl. & $\begin{array}{l}\text { Malvaceae (subfam. } \\
\text { Malvoideae) }\end{array}$ \\
\hline Silene fruticosa & Silene fruticosa $\mathrm{L}$. & Caryophyllaceae \\
\hline Solanum aculeatissimum & Solanum capsicoides All. & Solanaceae \\
\hline Solanum auriculatum & Solanum mauritianum Scop. & Solanaceae \\
\hline Solanum betaceum & Solanum betaceum Cav. & Solanaceae \\
\hline Solanum coccineum & irrisolto (PLK) & \\
\hline Solanum lycioides & Lycianthes lycioides (L.) Hassl. & Solanaceae \\
\hline Solanum niveum & Solanum giganteum Jacq. & Solanaceae \\
\hline Solanum pseudocapsicum & Solanum pseudocapsicum L. & Solanaceae \\
\hline Solanum pyracanthum & irrisolto (PLK) & \\
\hline Solanum sodomaeum & irrisolto: 2 omonimi & \\
\hline Solanum verbascifolium & Solanum donianum Walp. & Solanaceae \\
\hline Solanum triquetrum & Solanum triquetrum Cav. & Solanaceae \\
\hline Sparmannia africana & Sparmannia africana L. f. & $\begin{array}{l}\text { Malvaceae (subfam. } \\
\text { Dombeyoideae) }\end{array}$ \\
\hline Stapelia bufonia & Stisseria bufonia (Jacq.) Kuntze & Apocynaceae \\
\hline Stapelia europea & Caralluma europaea (Guss.) N.E. Br. & Apocynaceae \\
\hline Statice auriculaefolia & irrisolto: 5 omonimi & \\
\hline Statice bellidifolia & irrisolto: 7 omonimi & \\
\hline Statice cuneata & irrisolto (PLK) & \\
\hline Statice dichotoma & irrisolto: 7 omonimi & \\
\hline Statice trigonoides & irrisolto: 2 omonimi & \\
\hline Statice Oleaifolia & irrisolto: 5 omonimi & \\
\hline
\end{tabular}




\begin{tabular}{|c|c|c|}
\hline Nome secondo Balsamo Crivelli & Identità attuale del taxon & Famiglia \\
\hline Stevia ageratoides & epiteto non trovato & \\
\hline Stevia purpurea & irrisolto: 4 omonimi & \\
\hline Stevia serrata & Stevia serrata Cav. & Asteraceae \\
\hline Strelitzia Reginae & Strelitzia reginae Aiton & Strelitziaceae \\
\hline Stypandra caespitosa & Thelionema caespitosum (R. Br.) R.J.F. Hend. & $\begin{array}{l}\text { Xanthorrhoeaceae (subfam. } \\
\text { Hemerocallidoideae) }\end{array}$ \\
\hline Styrax off. & Styrax officinalis L. & Styracaceae \\
\hline Tagetes lucida & Tagetes lucida Cav. & Asteraceae \\
\hline Tamarindus indica & Tamarindus indica L. & Fabaceae \\
\hline Teucrium betonicum & Teucrium betonicum L'Hér. & Lamiaceae \\
\hline Teucrium flavum & Teucrium flavum L. & Lamiaceae \\
\hline Teucrium Marum & Teucrium marum L. & Lamiaceae \\
\hline Thalia dealbata & Thalia dealbata Fraser & Marantaceae \\
\hline Tournefortia foetidissimum & Tournefortia foetidissima L. & Boraginaceae \\
\hline Trachelium coeruleum & Trachelium caeruleum L. & Campanulaceae \\
\hline Tradescantia crassula & Tradescantia crassula Link \& Otto & Commelinaceae \\
\hline Tradescantia discolor & Tradescantia spathacea Sw. & Commelinaceae \\
\hline Triplaris americana & Triplaris americana L. & Polygonaceae \\
\hline Tristania laurina & $\begin{array}{l}\text { Tristaniopsis laurina (Sm.) Peter G. Wilson \& J.T. } \\
\text { Waterh. }\end{array}$ & Myrtaceae \\
\hline Twedia coerulea & $\begin{array}{l}\text { Oxypetalum coeruleum (D. Don ex Sweet) } \\
\text { Decne. }\end{array}$ & Apocynaceae \\
\hline Urtica baccifera & Urera baccifera (L.) Gaudich. & Urticaceae \\
\hline Varronia martinicensis & Cordia martinicensis (Jacq.) Roem. \& Schult. & Boraginaceae \\
\hline Veltheimia viridiflora & Veltheimia viridiflora hort. & $\begin{array}{l}\text { Asparagaceae (subfam. } \\
\text { Scilloideae) }\end{array}$ \\
\hline Verbesina atriplicifolia & Montanoa atriplicifolia (Pers.) Sch. Bip. & Asteraceae \\
\hline $\begin{array}{l}\text { Vesicaria macrocarpa }(\rightarrow \\
\text { microcarpa) }\end{array}$ & Aurinia petraea (Ard.) Schur & Brassicaceae \\
\hline Viburnum tinus & Viburnum tinus L. & Adoxaceae \\
\hline Vinca alba & $\begin{array}{l}\text { Tabernaemontana divaricata (L.) R. Br. ex } \\
\text { Roem. \& Schult. }\end{array}$ & Apocynaceae \\
\hline Vinca rosea & Catharanthus roseus (L.) G. Don & Apocynaceae \\
\hline Virgilia aurea & Calpurnia aurea (Aiton) Benth. & Fabaceae \\
\hline Visnea mocanera & Visnea mocanera L. f. & Pentaphylacaceae \\
\hline Yucca aloifolia & Yucca aloifolia L. & $\begin{array}{l}\text { Asparagaceae (subfam. } \\
\text { Agavoideae) }\end{array}$ \\
\hline Yucca Draconis & Yucca aloifolia L. & $\begin{array}{l}\text { Asparagaceae (subfam. } \\
\text { Agavoideae) }\end{array}$ \\
\hline Zamia quachicola (?) & epiteto non letto & \\
\hline Zamia pumila & Zamia pumila L. & Zamiaceae \\
\hline
\end{tabular}




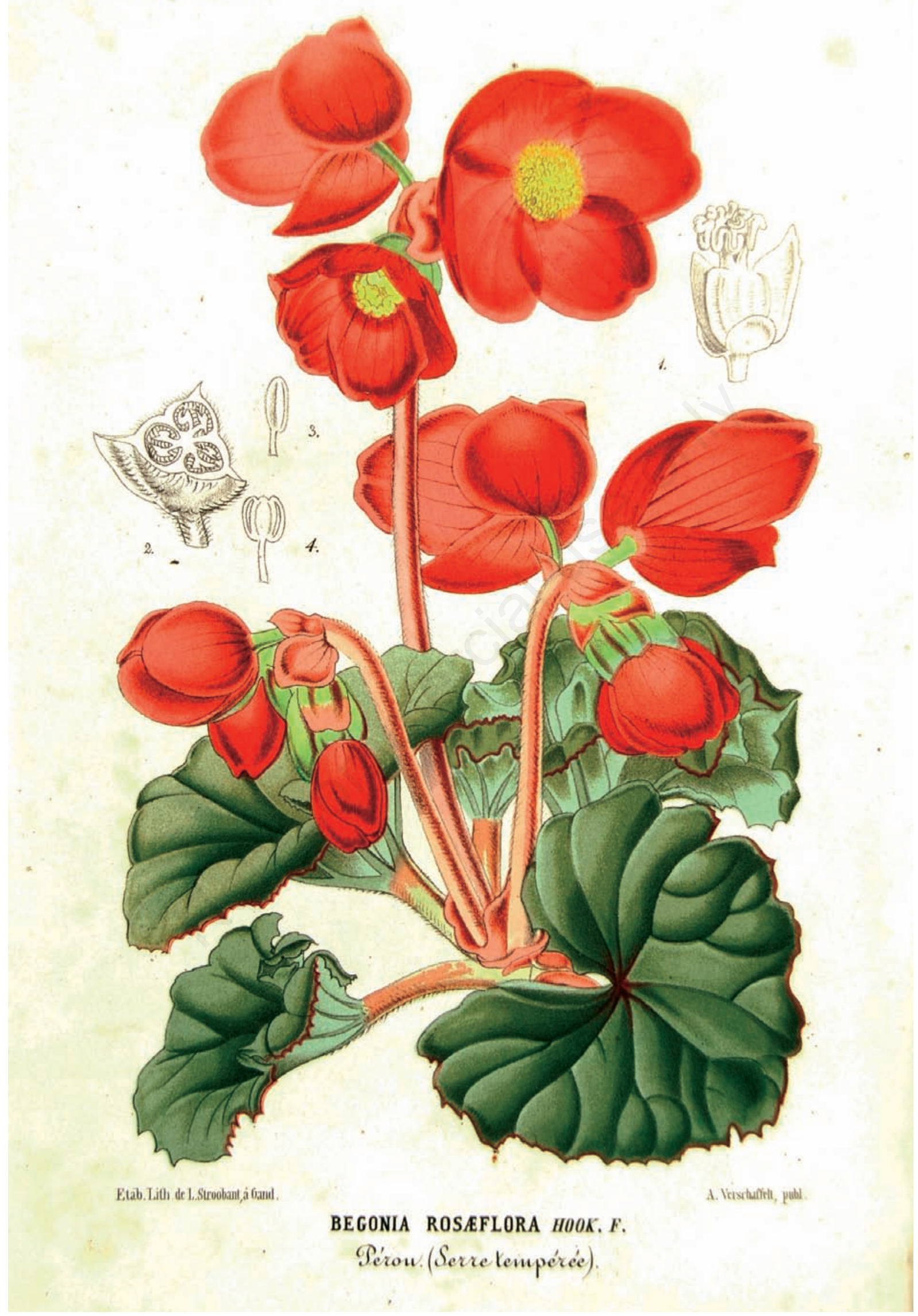

Fig. 1 - Begonia veitchii Hook. f. (Begoniaceae) (Lemaire Ch. (redigé par), 1868 - L’illustration horticole, Gand, 15, tav. 553). 


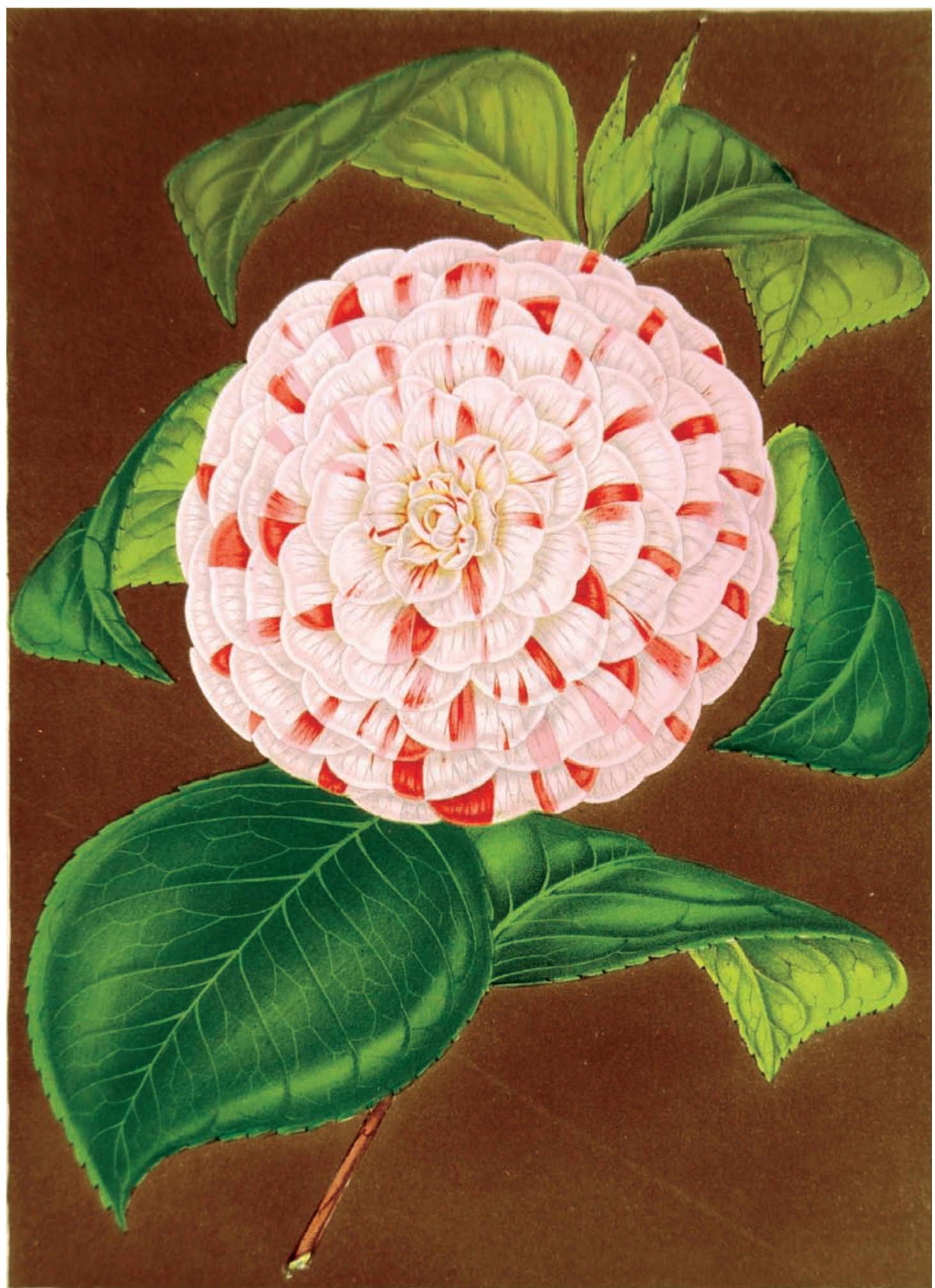

(a), Lin, deL.Strobart, i Gand,

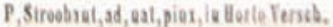

CAMELLIA MADAME AMBROISE VERSCHAFFELT.

Semio. Jatie. (Serrefroide.)

A, Verechalfeli pabi,

Fig. 2 - Camellia 'M.me Ambroise Verschaffelt' (Theaceae) (Lemaire Ch. (redigé par), 1868 - L'illustration horticole, Gand, 15, tav. 546). 


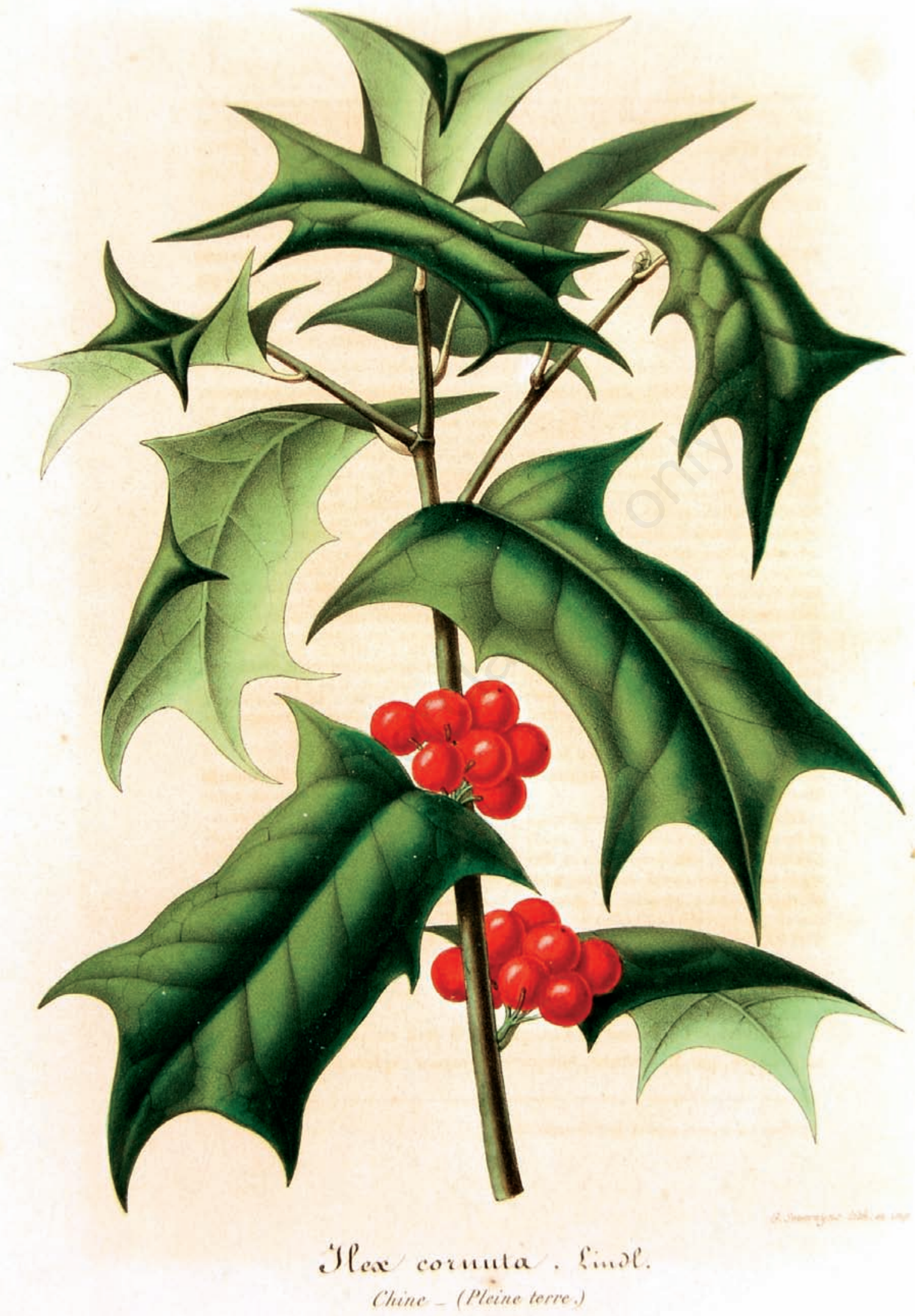

Fig. 3 - Ilex $\times$ cornuta Lindl. \& Paxton pro sp. (Aquifoliaceae) (Lemaire Ch. (redigé par), 1854 - L'illustration horticole, Gand, 1, tav. 10). 


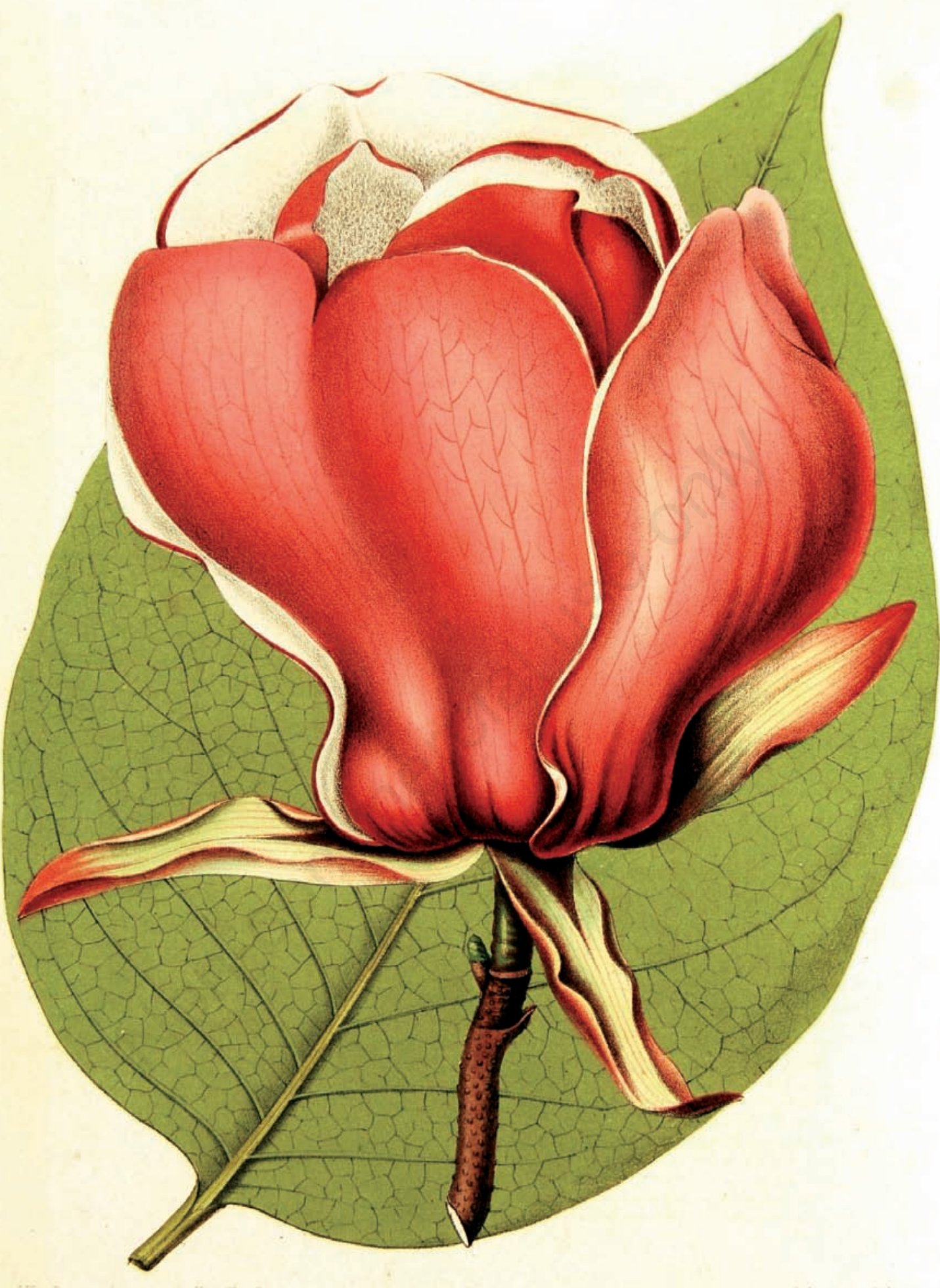

Illaguolia Senué ( Sybzide).

Italic (sermis) - Plain air.

Fig. 4 - Magnolia $\times$ soulangeana Soul.-Bod. (Magnoliaceae) (Lemaire Ch. (redigé par), 1854 - L’illustration horticole, Gand, 1, tav. 37). 


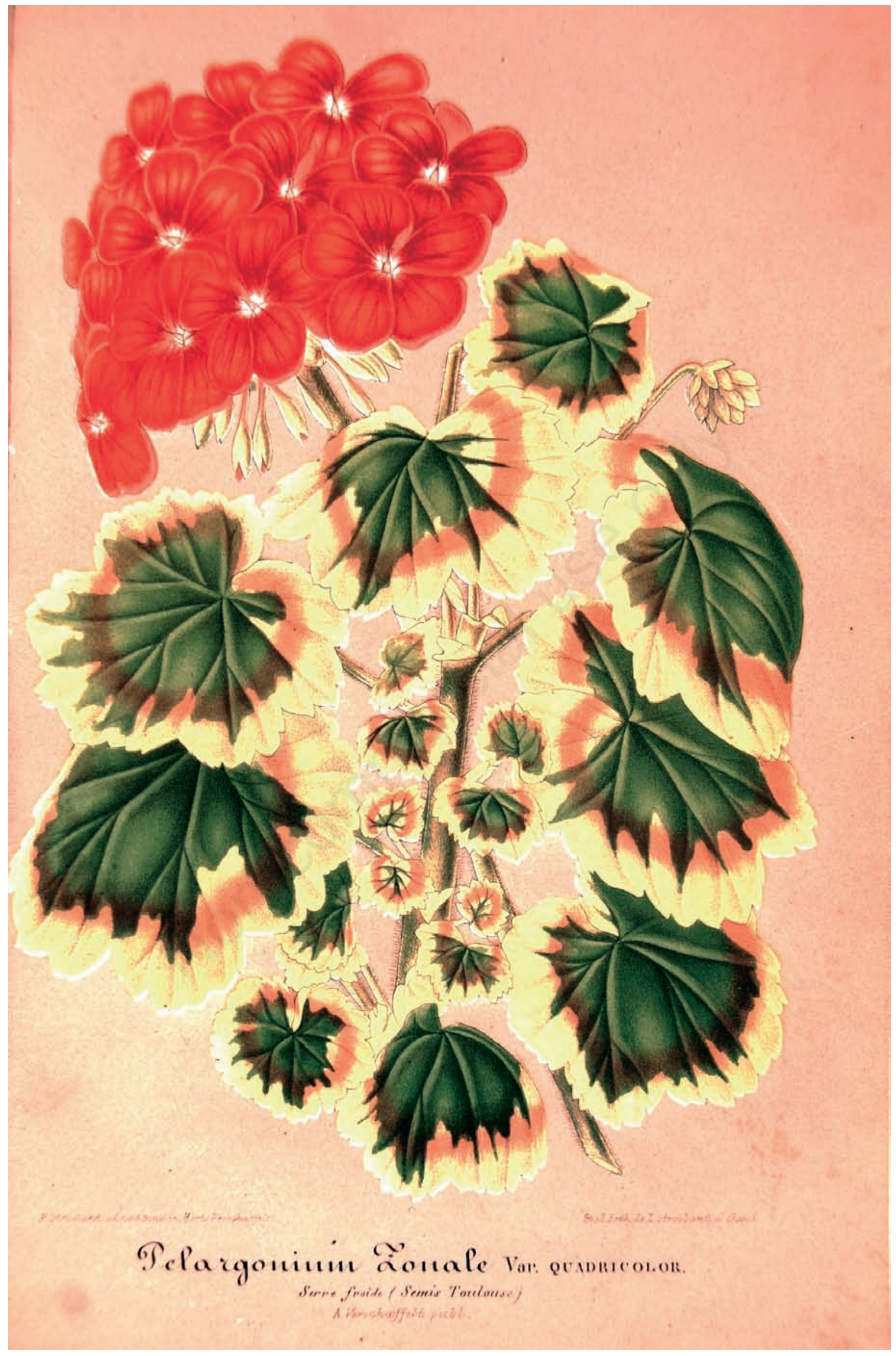

Fig. 5 - Pelargonium zonale (L.) L'Hérit. (Geraniaceae) (Lemaire Ch. (redigé par), 1862 - L'illustration horticole, Gand, 9, tav. 346). 


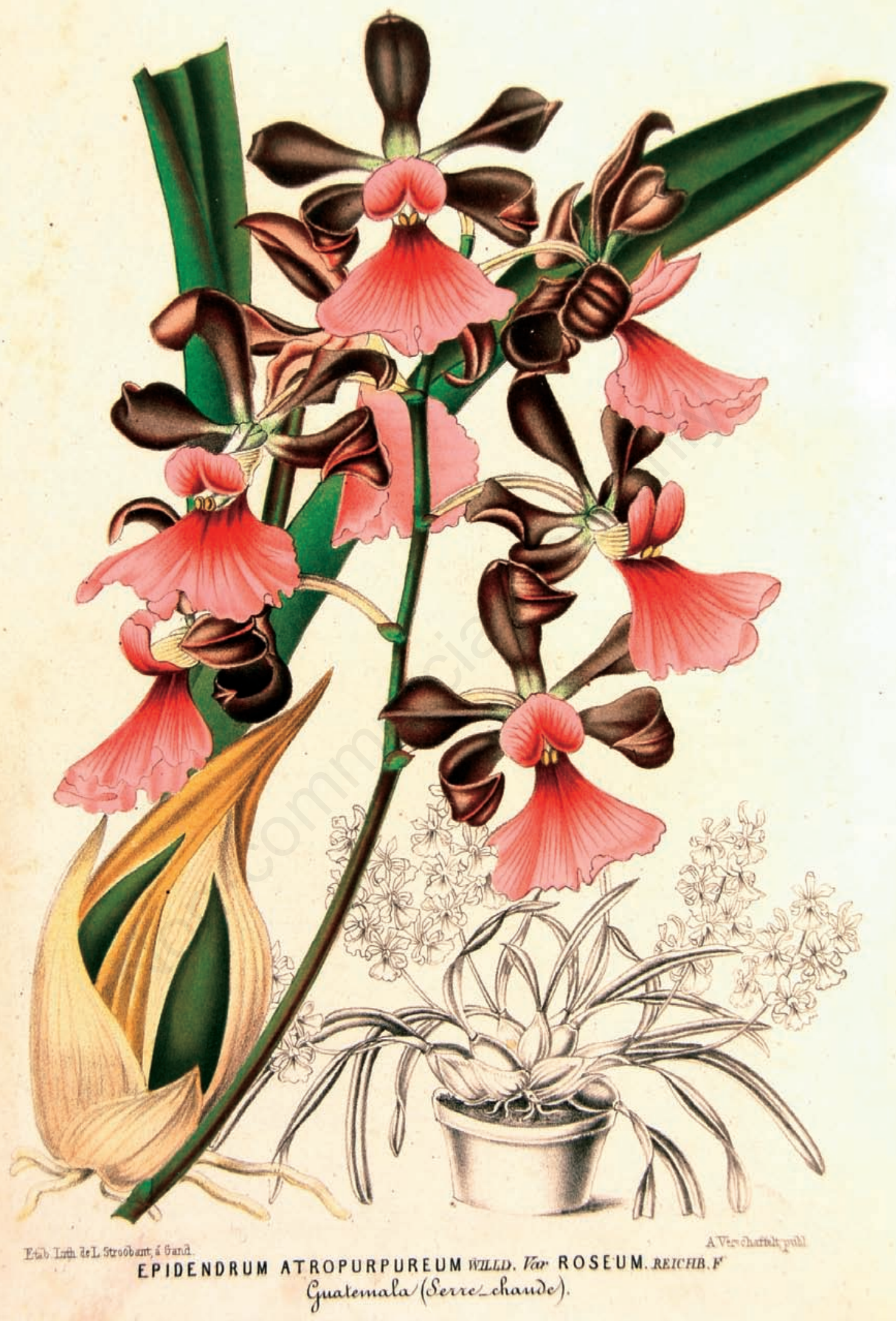

Fig. 6 - Psychilis purpurea (Willd.) Sauleda 'Rosea' (Orchidaceae) (Lemaire Ch. (redigé par), 1868 - L'illustration horticole, Gand, 15, tav. 544). 


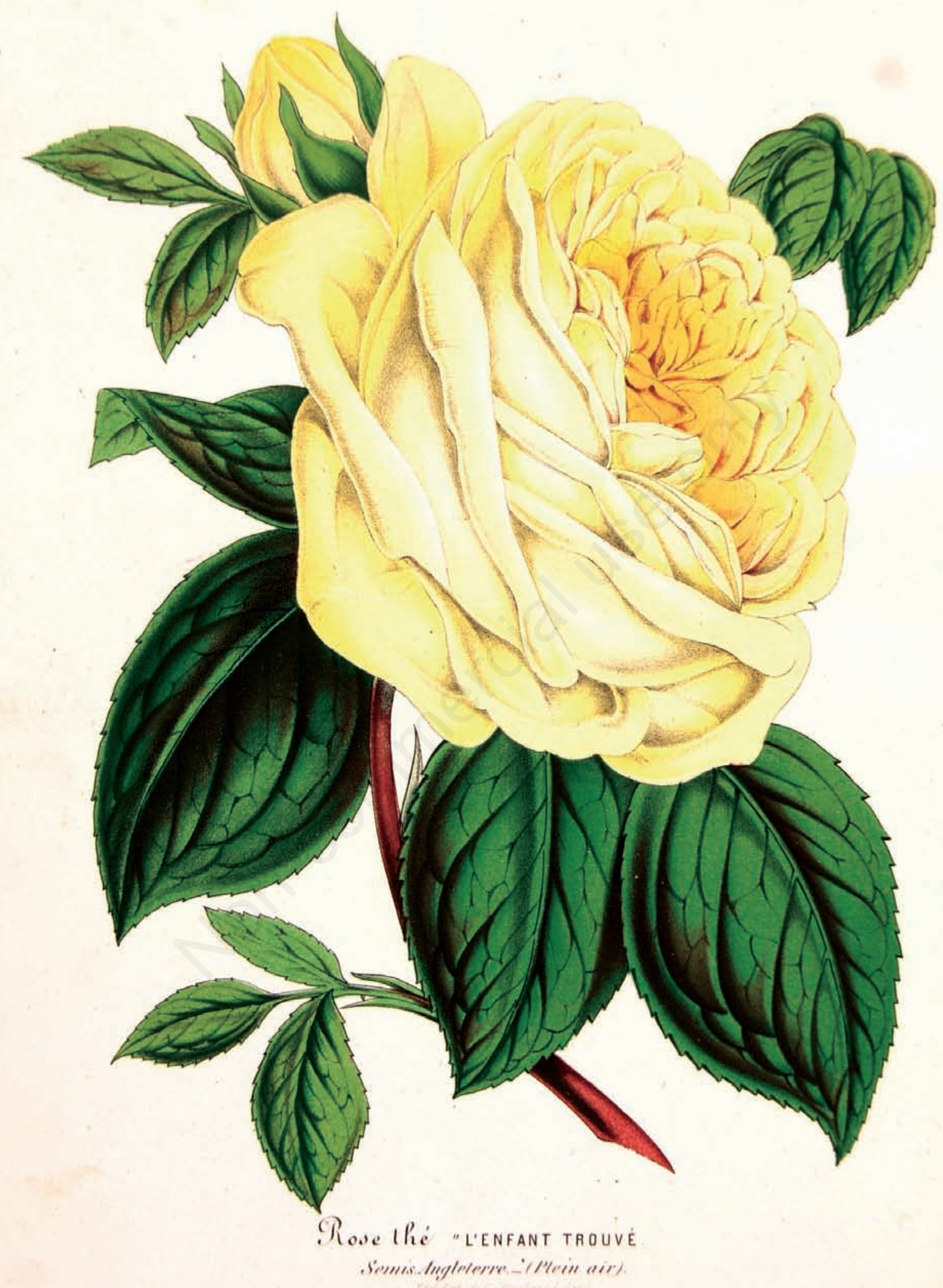

Fig. 7 - Rosa Gruppo Tea 'L'enfant trouvé' (Rosaceae) (Lemaire Ch. (redigé par), 1862 - L'illustration horticole, Gand, 9, tav. 334). 


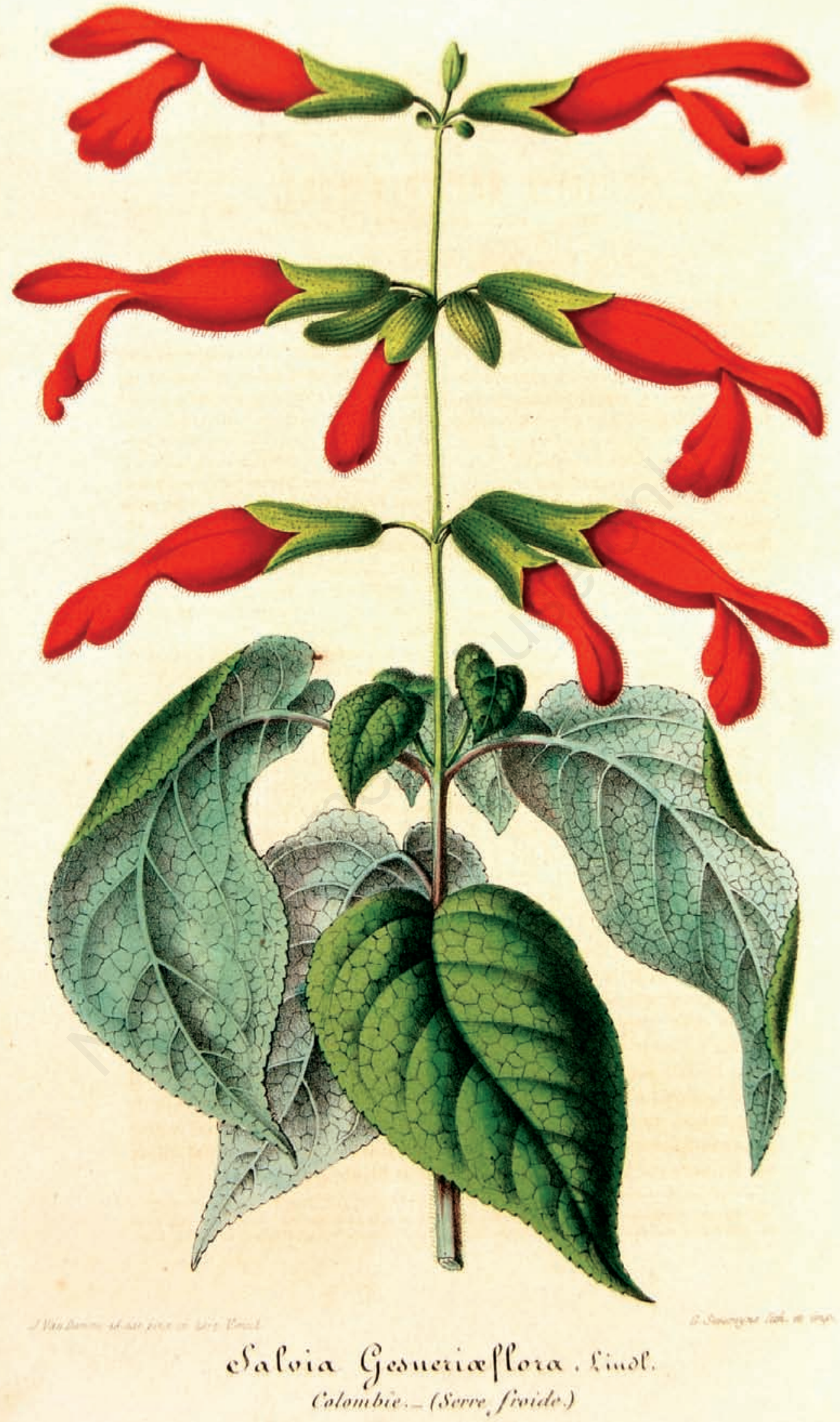

Fig. 8 - Salvia gesneriiflora Lindl. \& Paxton (Lamiaceae) (Lemaire Ch. (redigé par), 1854 - L'illustration horticole, Gand, 1, tav. 32). 